\title{
VOLUNTARY VS MANDATORY CORPORATE GOVERNANCE: TOWARDS AN OPTIMAL REGULATORY FRAMEWORK
}

BY

\author{
Anita Indira Anand**
}

** Visiting Olin Scholar in Law and Economics, Yale Law School (2005-2006); Associate Professor, Faculty of Law, Queen's University, Kingston, Ontario, Canada, K7L 3N6. Telephone: 613-533-6000 (74287) and e-mail: aa7@ post.queensu.ca. Thanks to Bernard Black, Kim Brooks, Doug Harris, Edward Iacobucci, Lewis Johnson, John Knowlton, Kate Litvak, Niamh Maloney, Marc Paulez, Jessie Penley, Larry Ribstein and Michael Trebilcock for their very helpful comments and to Jessie Penley and Ryan Sheahan for their excellent research assistance. I extend my appreciation to the Queen's University Advisory Research Council, the Foundation for Legal Research, and the Social Sciences and Humanities Research Council of Canada for assistance in funding research underlying this project. In 2004, this paper was presented at the Queen's Law and Economics Discussion Group and the annual conference of the Canadian Law and Economics Association. I extend my appreciation to participants at these sessions for their helpful comments. 


\begin{abstract}
This article fills a gap in the legal literature by comparing mandatory corporate governance regimes to voluntary corporate governance regimes. It encourages market participants, including regulators, to acknowledge that firms have incentives to adopt enhanced governance practices voluntarily and to make disclosure about the same. The article argues that an optimal governance regime is a hybrid one in which adoption of best practice guidelines is voluntary but disclosure of corporate governance practices is mandatory. Such a regime is optimal because it balances the benefits and costs to all stakeholders, particularly issuers and investors. The cost analysis should be completed by weighing the level of expected compliance against the total costs of the regime adopted by regulators. A partially mandatory structure is likely to yield a high level of compliance with a defined set of governance practices at lower cost than a wholly mandatory regime. While a wholly mandatory structure may yield slightly better compliance, its costs are likely much higher. Thus, a partially mandatory structure that minimizes costs but encourages compliance is optimal.
\end{abstract}




\section{CONTENTS}

I INTRODUCTION

II MANDATORY VS. VOLUNTARY GOVERNANCE STRUCTURES .........

a) Minimum Standards

b) Compliance Levels

c) Costs to Investors

d) Costs to Firms and to the State

e) Flexibility

\section{INCENTIVES FOR VOLUNTARY BEHAVIOUR .............................................}

a) Incentives to Adopt Corporate Governance Practices Voluntarily

b) Incentives to Disclose Information Voluntarily

IV IMPLICATIONS FOR DEVISING A LEGAL REGIME..................................

a) Comparative Analysis by Jurisdiction

b) Choosing a Governance Structure

c) Flexibility in Governance Structures 


\section{Introduction}

In capital markets regulation, the established legal regime is a command-and-control structure in which public officials establish the law and market actors either comply or face penalties. Corporate governance has stood apart from the command and control model as an area in which companies have been permitted to design and structure their own practices, within certain boundaries. Recently in the United States, various aspects of corporate governance have become the subject of mandatory regulation. Other common law jurisdictions have chosen to adopt partially mandatory structures by allowing companies to make choices about their governance but compelling disclosure regarding these choices. The question that arises is whether a wholly mandatory, a wholly voluntary, or some compromise governance regime is optimal.

In response to this question, proponents of the free market would argue that a mandatory regime is unnecessary: If enhanced corporate governance practices are beneficial and desired by investors, firms competing for scarce capital will implement them voluntarily. On the other hand, investor advocates would argue that a voluntary regime is insufficient, since there is no guarantee that all firms will implement the reforms necessary to provide investors with adequate checks on management and board control. Mandatory rules, on this view, are necessary to protect investors and, in turn, to build confidence in the capital markets.

This article contends that the extreme positions on either side of this spectrum are undesirable and that a partially mandatory regime is optimal. An optimal regime, it is argued, is one that takes into account the benefits and costs to all stakeholders, particularly issuers and investors. While the benefits of a corporate governance regime (such as accountability) are relatively clear, the corresponding costs (such as compliance) are not. The cost analysis can be completed by weighing the level of expected compliance against the aggregate costs of the regime. A partially mandatory structure is likely to yield a high level of compliance at lower cost than a wholly mandatory regime. While a wholly mandatory structure may yield slightly better compliance, its costs are likely to be much higher. Thus, a partially mandatory structure that minimizes costs but encourages a high level of compliance is optimal. This use of the term "optimal" describes a regime (i.e., the partially mandatory regime) that is preferred because its 
costs are less than its benefits and because it provides virtually the same benefits as an alternative structure (i.e., the mandatory structure), but at a lower cost.

This article fills a gap in the academic literature from several different perspectives. Up to this point, voluntary behavior in capital markets has not been studied with an emphasis on corporate governance practices and regimes. In the economics field, academics have studied mandatory and voluntary disclosure and optimal disclosure levels. ${ }^{1}$ In the environmental literature, academics have studied firms' willingness to adopt more environmentally responsible practices through negotiated agreements with authorities. ${ }^{2}$ More recently, Gompers, Ishii, and Metrick have examined the link between corporate governance practices and share price. ${ }^{3}$

This article builds on the relevant work in these areas and works toward a conception of optimality in the structure of a corporate governance regime. First, it applies theories of voluntary behavior to corporate governance issues, examining firms' incentives to adopt corporate

\footnotetext{
1 See e.g. George J. Benston, "Required Disclosure and the Stock Market: An Evaluation of the Securities Exchange Act of 1934" (1973) 63 AM. ECON. REV. 132; Robert E. Verrecchia, "Consensus Beliefs, Information Acquisition and Market Information Efficiency" (1980) 70 AM. ECON. REV. 874; Robert E. Verrecchia, "Discretionary Disclosure" (1983) 5 J. ACCT. \& ECON. 179; Joel Seligman, "The Historical Need for a Mandatory Corporate Disclosure System" (1983) 9 J. CoRP. L. 1; Frank H. Easterbrook \& Daniel R. Fischel, "Mandatory Disclosure and the Protection of Investors" (1984) 70 VA. L. REV. 669; John C. Coffee Jr., "Market Failure and the Economic Case for a Mandatory Disclosure System" (1984)70 VA. L. REV. 717; Sidney J. Gray \& Clare B. Roberts, "Voluntary Information Disclosure and the British Multinationals: Corporate Perceptions of Costs and Benefits" in InTERNATIONAL PRESSURES FOR ACCOUNTING CHANGE 116 (Anthony G. Hopwood ed., 1989); Douglas W. Diamond \& Robert E. Verrecchia, "Disclosure, Liquidity and the Cost of Capital" (1991) J. OF FIN. 1325; Christian Leuz \& Robert E. Verrecchia, "The Economic Consequences of Increased Disclosure" (2000) 38 J. OF ACCT. RES. 91; Paul M. Healy \& Krishna G. Palepu, "Information Asymmetry, Corporate Disclosure and the Capital Markets: A Review of the Empirical Disclosure Literature" (2001) 31 J. OF ACCT. \& ECON. 405; Meridee Bujaki \& Bruce J. McConomy, "Corporate Governance: Factors Influencing Voluntary Disclosure by Publicly Traded Canadian Firms" (2002) 1 CAN. ACCT. PERSPECTIVES 105.

2 See e.g. Seema Arora \& Timothy N. Cason, "An Experiment in Voluntary Environmental Regulation: Participation in EPA's 33/50 Program" (1995) 28 J. ENVTL. ECON. \& MGMT. 271; Seema Arora \& Shubhashis Gangopadhyay, "Toward a Theoretical Model of Voluntary Overcompliance" (1995) 28 J. ECON. BEHAV. \& ORG. 289 (1995); Seema Arora \& Timothy N. Cason, "Why Do Firms Volunteer to Exceed Environmental Regulations? Understanding Participation in EPA's 33/50 Program” (1996) 72 LAND ECON. 413; Kathleen Segerson \& Thomas J. Micelli, "Voluntary Environmental Agreements: Good or Bad News for Environmental Protection?" (1999) 36 J. EnVtL. Econ. \& MGMT. 109; Madhu Khanna \& Lisa Damon, "EPA Voluntary 33/50 Program: Impact on Toxic Releases and Economic Performance of Firms" (1999) 37 J. EnVTL. ECON. \& MGMT. 1; John W. Maxwell, Thomas P. Lyon \& Steven C. Hackett, "Self-Regulation and Social Welfare: The Political Economy of Corporate Environmentalism" (2000) 43 J. L. \& ECON. 583.

3 Paul A. Gompers, Joy L. Ishii \& Andrew Metrick, "Corporate Governance and Equity Prices" (2003) Q. J. ECON. 107. See also Raphael La Porta, Florencio Lopez-de-Silanes \& Andrei Shleifer, "What Works in Securities Laws?" (2004) (unpublished manuscript, on file with author) at <http://post.economics.harvard.edu/faculty/shleifer/papers/securities_final.pdf>.
} 
governance practices and make disclosure voluntarily. Second, the article examines voluntary disclosure of information specifically relating to corporate governance practices, an issue that has not received much academic attention compared to studies of voluntary disclosure generally. Finally, the article compares corporate governance regimes in various jurisdictions and identifies the extent to which these regimes are mandatory or partially mandatory. This comparative examination is used to support the argument that a partially mandatory regime is optimal.

To be clear, the term "mandatory" as used here means legally mandated with penalties imposed on those who fail to comply with the legal rule. "Voluntary" denotes a firm's adoption of corporate governance practices or standards in the absence of a legal requirement to do so. ${ }^{4}$ Such practices can, but need not be, set forth in guidelines ${ }^{5}$ or best practice regulatory instruments, ${ }^{6}$ typically issued by securities regulators or stock exchanges. The voluntary code does not replace but is an addition to a corporate governance regime already in place in statute.

The term "corporate governance" generally refers to the internal structure under which corporations operate. ${ }^{7}$ Another commonly used definition views corporate governance as "the process and structure established to direct and manage the business and affairs of the corporation with the objective of enhancing shareholder value." ${ }^{\prime 8}$ Central to the concept of corporate governance is the division of power between the board of directors and other corporate stakeholders, including management and shareholders.

$4 \quad$ There is also a "hybrid" type of rule, which is the type of rule that firms comply with because they feel compelled to do so for any number of reasons, such as to avert the loss of capital that would occur if they did not do so. In other words, firms would adopt these hybrid-type rules even if they were not required to do so. These also fall into the "voluntary" category. See infra Part III on incentives.

$5 \quad$ See e.g. Guidelines, in Toronto Stock Exchange, TSX COMPANY MANUAL $\$ 474$ (2004), at http://www.tse.com/en/pdf/CompanyManual.pdf [TSX Guidelines].

6 See e.g. Ontario Security Commission, Proposed Multilateral Instrument 58-101: Disclosure of Corporate Governance Practices, online: Ontario Securities Commission Policy \& Regulation http://www.osc.gov.on.ca/Regulation/Rulemaking/Current/Part5/rule_20040116_58-101_multi-instru.jsp [MI 58101]. Note that MI 58-101 is not yet in force.

$7 \quad$ For discussion, see Janis Sarra, "Convergence Versus Divergence, Global Corporate Governance at the Crossroads: Governance Norms, Capital Markets \& OECD Principles for Corporate Governance” (2001-2002) 33 Ottawa L. Rev. 177.

8 See Toronto Stock Exchange Committee on Corporate Governance in Canada, "Where Were the Directors?” Guidelines for Improved Corporate Governance in Canada, Guideline (12)(i), (1994) [Dey Report]. 
However, these definitions do not reflect the understanding of the term used here. They speak only of the relationships between those who run the company and those who invest or otherwise deal with it. Given the broad range of corporate governance initiatives in many jurisdictions, it is clear that the concept continues to expand. Thus, a more appropriate definition of "corporate governance" includes additional components contained in these initiatives, such as disclosure of board composition, including the number of independent directors on the board; composition of various committees of the board; and separation of chair of the board and CEO. ${ }^{9}$

The argument advanced here has both descriptive and prescriptive elements. It is descriptive in its attempt to illustrate the benefits and drawbacks of both mandatory and voluntary regimes. The article also outlines for comparative purposes the different corporate governance regimes in place in the major common law countries (the US, Canada, Australia and the UK). However, the article is also prescriptive in putting forth an argument in favour of a partially mandatory regime as one that is ultimately preferable to a purely mandatory or purely voluntary system.

Part II of this article argues against a wholly mandatory approach to corporate governance regulation and, in so doing, highlights the benefits of a voluntary structure. Part III contends that there are powerful incentives for voluntary behavior in the area of corporate governance. Part IV examines policy implications of recognizing that firms have incentives to adopt governance practices voluntarily, arguing in favor of a partially mandatory structure in which firms have the flexibility to design their own corporate governance regime but must disclose the particulars of that regime. Part V concludes.

\section{Mandatory vs. Voluntary Governance Structures}

The traditional legal regime for any regulated activity is a scheme of rules that prescribes certain behavior, supported by penalties to which those who break the law are subject. This model, which supposes that the primary incentive for compliance is fear of the consequences of

\footnotetext{
$9 \quad$ An even broader understanding of corporate governance is sometimes employed by corporate stakeholders. For some, corporate governance can be understood to encompass and apply to any practice which, from a
} 
non-compliance, can be termed a "command-and-control" structure. This section notes the benefits and costs of a command-and-control governance regime and compares these with the benefits and costs of a voluntary regime, using five interrelated points of reference: minimum standards, compliance levels, costs to investors, costs to firms, and flexibility.

\section{a. Minimum Standards}

A major advantage of the mandatory structure is that it allows the state to establish minimum standards to which market participants must adhere. If the state accords primary importance to investor protection, as it does in passing corporate governance legislation, then it will seek to ensure that this objective is achieved. One of the ways it will do this is to implement mandatory legislation. While there is no definite connection between investor protection and a mandatory system, the state is able to achieve its goal directly because market participants will be compelled to comply, since they do not wish to face the penalty of non-compliance. By contrast, purely voluntary legislation provides no guarantees that the minimum governance standards established by the state will be achieved.

There are further societal benefits of a mandatory regime. There is evidence that regimes with strong investor protection lead to healthy capital markets. La Porta et al. have found that in countries with better legal protections for investors, financial markets are more developed. They analyzed the securities laws of 49 countries and found that financial markets do not prosper when left to market forces alone. In their study, both disclosure rights and liability standards were positively correlated with larger stock markets, while public enforcement, such as an independent regulator or criminal sanctions, were found to play a modest role in the development of stock markets. These findings suggest that securities laws matter because they lead to strong markets by facilitating private contracting. ${ }^{10}$

shareholders' perspective, takes value away from them.

10 Rafael La Porta, Florencio Lopez-de-Silanes, \& Andrei Shleifer, supra note 3 at $12-13$. See also Rafael La Porta, Florencio Lopez-de-Silanes, Andrei Shleifer, \& Robert W. Vishny, Legal Determinants of External Finance, J. OF FIN. 52, 1131 (1997), who argue that countries with poorer investor protection have smaller and narrower capital markets. French civil law countries have the weakest investor protection, and the least developed capital markets, compared to common law countries. 
This is not to say, however, public regulatory enforcement has no role in the development of healthy capital markets. On the contrary, in an earlier study, La Porta et al. argued that the differences in the efficacy of financial systems can be traced in part to differences in investor protections against expropriation by insiders. ${ }^{11}$ These differences are reflected in both the legal rules and the quality of their enforcement in a given country. Indeed, La Porta et al present data that illustrate the vast differences across countries in legal rules aimed at investor protection and the quality of the enforcement of these rules. In countries with strong legal protections, capital markets are larger since, as La Porta et al argue, potential investors are shielded against expropriation by entrepreneurs. ${ }^{12}$

Thus, a mandatory governance regime would be important in enabling the state to inculcate, or at least uphold, the principle of investor protection as well as to develop healthy capital markets. However, it must be remembered that corporate governance reforms are additions to a legal regime that is already mandatory in nature. Thus, it is possible to conceive of a state's achieving the goal of investor protection while some aspects of its overall capital markets regulation remain voluntary or, at least, partially voluntary. We will return to this possibility in Part IV below.

\section{b. Compliance Levels}

There are other benefits to a command-and-control regime, such as broad-based compliance. Compliance will be especially high if the penalties for non-compliance are onerous. Further, if the regime has been in place for a number of years, and market participants are aware of the "rules of the game," including punishments in the case of breach, the regime exhibits consistency. Because of this broad-ranging compliance, the legal regime also has a certain predictability. The well-founded assumption is that once the regime is implemented, the number of actors who deviate from the regime will be much smaller than the number of actors who

\footnotetext{
11 Rafael La Porta, Florencio Lopez-de-Silanes, Andrei Shleifer and Robert W. Vishny, 1996, Law and Finance, NBER Working Paper 5661. See also La Porta et al, ibid. at 1131.

$12 \quad$ La Porta et al., supra note 10 at 1149.
} 
comply. ${ }^{13}$ Thus, rates of compliance over time in a mandatory regime are both consistent and predictable.

Compliance is one of the more significant weaknesses of voluntary regimes. If the state establishes a set of guidelines or best practices to be followed, there is no assurance that market actors will abide by them, since they are not mandatory and no penalty attaches to those who fail to comply. Furthermore, rates of compliance are inconsistent. This may occasion other costs associated with a voluntary system, including the information costs incurred by investors to determine the governance practices of the firm and to assess them in relation to other firms' practices. As noted, mandatory rules achieve their objective more directly: If the state wants to achieve a certain objective, it need only set forth the legal rules and the general populace will follow them, with few deviations.

While voluntary regimes are less direct, they can nevertheless encourage compliance in the long term. As more and more firms adopt corporate governance practices over time, these voluntary practices become the norm among a majority of firms. This is the "snowball" or "cluster effect" that is discussed throughout this article. An example of this effect may be the separation of the roles of chair of the board and CEO, at least in Canada and the United States, where more and more firms seem to be adopting this practice since the 1994 Dey Committee Guidelines. ${ }^{14}$ Thus, it is not necessarily true that compliance is poor, or does not increase, under a voluntary regime.

Some may question whether peer pressure from firms within an industry to adopt heightened governance practice renders these practices in effect mandatory. This is the idea that "we have to adopt this practice because our competitors are doing so.” In my view, when firms

13 See Darren Sinclair, "Self-Regulation Versus Command and Control? Beyond False Dichotomies" (1997) 19 Law and Policy 529 at 534.

14 See Dey Report, supra note 8. The Globe \& Mail's 2003 "Board Games" study found that 65\% of companies in the S\&P/TSX index had separated the roles of chair of the board and CEO. See Board Games, The Globe and Mail (7 October 2002) B1, online: The Globe \& Mail

<http://www.theglobeandmail.com/series/boardgames/stories/20021007main.html>. See also Phyllis Plitch "Post of Lead Director Is Catching On" Wall Street Journal (7 July 2004) 1, which states not only that more U.S. companies are separating the roles of chair and CEO, but also that "[m]ore and more U.S. companies are naming lead directors, embracing the increasingly popular board position as a palatable alternative to separating the chairman and chief executive jobs." 
respond to industry pressure, we should think about this as one of the beneficial effects of voluntary behaviour. A mandatory rule is mandatory because it carries with it legal not financial or competitive pressure or sanctions. Where a firm chooses to adopt a practice in the absence of a legal requirement to do so, this is an example of voluntary behaviour. As discussed below, not all firms have adopted these "voluntary" standards but a high percentage of them have done so.

\section{c. Costs to Investors}

Corporate law is no stranger to mandatory rules. ${ }^{15}$ Well-established mandatory rules relate to the process of incorporation, ${ }^{16}$ the level of shareholder approval that must be reached for an ordinary or special resolution to be passed, ${ }^{17}$ and the authority of agents to contract on behalf of the firm. ${ }^{18}$ Mandatory rules such as these are intended to protect investors; they maintain a discernible and seemingly fair process for making corporate decisions. Mandatory rules relating to disclosure can be especially useful to uninformed and unsophisticated investors: They stand as a shield for these investors against the information asymmetries to which they are subject. ${ }^{19}$ This is a theme to which we return in the last section of the paper.

A mandatory governance system decreases the cost of becoming an informed investor. An informed investor would like to know what the governance practices of company $x$ are and how they compare with the governance practices of company $y$. Under a mandatory governance system, assessing the relative strength of the companies' governance practices is straightforward: Since each company's governance practices are based on the mandatory governance regime, a rational investor can use the same terms of reference - namely, the rules embodied in that regime - to asess potential investments. The law thus constitutes a standard form, and investors need only learn the terms of reference of one system. The costs of learning those terms of reference can be spread out among as many companies as the investor assesses.

15 See Jeffrey N. Gordon, “The Mandatory Structure of Corporate Law” (1989) 89 COLUM. L. REV. 1549 . Some would dispute this fact. See Roberta Romano, "Answering the Wrong Question: The Tenuous Case for Mandatory Corporate Laws" (1989) 89 COLUM. L. REV. 1599, arguing that so-called mandatory rules can easily and legally be bypassed and are thus not mandatory in the ordinary understanding of the word. See also Bernard Black, "Is Corporate Law Trivial?: A Political and Economic Analysis" (1990) 84 N. W. U. L. REV. 542 .

16 See e.g. Canada Business Corporations Act, R.S.C. 1985, c. C-44, §§ 5-12 [hereinafter CBCA].

17 See e.g. ibid., § 2(1) Definitions at "ordinary resolution" and "special resolution."

18 See e.g. ibid., $\$ 18$. 
Contrast this with the costs of becoming an informed investor under a purely voluntary governance system. Under such a system, companies are free to set their own terms of reference. There is less certainty for investors that the firm is indeed complying with the guidelines. This makes it difficult for investors to assess the relative strength of a company's governance practices; the practices of different companies are not inherently comparable. The investor must learn about the governance regime that each individual company has adopted. Therefore, the investor incurs more costs for each company she assesses. In sum, even in a voluntary system where the state has established a code of best practices, the investor is less able to spread the costs of becoming informed because she will be unaware of the particular governance regime that any one firm has adopted. ${ }^{20}$

The voluntary code may be viewed as a standard form if it is followed by a majority of issuers or if the corporate governance regime compels disclosure of whether and to what extent a firm has complied with the governance guidelines. Compulsory disclosure has been the practice in Canada since 1995, when the Toronto Stock Exchange indicated to listed firms that mandatory disclosure regarding compliance with the voluntary guidelines was required. ${ }^{21}$ As will be discussed, a number of countries have adopted this policy, although the United States has not. Thus, at least under a partially voluntary regime, voluntary codes can exist as a standard form, allowing investors to refer to standardized disclosure.

\section{d. Costs to Firms and to the State}

While a command-and-control model is cost-effective for investors, it is costly for the state and, of course, for the firm. In implementing a governance regime, the state will bear policy design cost, implementation costs and enforcement costs. Enforcement costs include costs of monitoring the market for abuses. In addition, costs to firms arise from monitoring and assessing

\footnotetext{
19 Gordon, supra note 15 at 1556.

20 This will not be the case if disclosure about the governance regime is mandatory. See the discussion in Part IV, below. Note however that even under a hybrid system, the investor must still assess the impact of different (disclosed) governance practices on investor protection, and whether they are "efficient" for the particular firm. 21 In 1999, the TSX stated that the disclosure should take a certain format. See letter from Clare Gaudet, Vice President Corporate Finance Services, Toronto Stock Exchange (Nov. 17, 1999) (on file with author).
} 
their own practices (e.g., conducting internal control reviews); implementing new governance structures; producing disclosure and reports; and, distributing disclosure. There may be hidden costs that arise ex post the implementation of the mandatory structure, such as increased insurance premiums for directors or officers who are required to certify financial statements. ${ }^{22}$ Of course, the presence and extent of each of these costs will depend on the content of the mandatory legislation itself (i.e., what does the law require?).

As discussed in Part IV below, many but not all of these costs would also exist under a voluntary regime. But two costs in particular will be reduced (though not necessarily eliminated) in the voluntary structure. First are the issuer's compliance costs, which can be divided into direct and indirect categories. Direct compliance costs include fees that must be filed prior to or following a transaction. While these costs may not decrease under a voluntary system, indirect compliance costs certainly would. Indirect compliance costs include internal management costs, or the internal costs that an actor bears to organize itself to comply with a legal rule. For example, under the Sarbanes-Oxley Act, management has direct responsibility for the assessment of internal controls, with disclosure in the annual report regarding the internal control structure and an assessment of the effectiveness of that structure. ${ }^{23}$ Management will incur significant costs not only in establishing and maintaining the internal controls but also for drafting and issuing the appropriate disclosure. These costs would not necessarily arise under a voluntary structure, since firms decide which costs they wish to incur and when. ${ }^{24}$

22 The Sarbanes-Oxley Act of 2002, Pub. L. No. 107-204, 116 Stat. 745 (codified in scattered sections of 15 U.S.C. and 18 U.S.C.) [hereinafter SOX] is an example of costly mandatory legislation. A recent survey found that compliance costs will be US\$5.5 billion in 2004. Costs to the issuer now include restructuring the board and finding CEOs and CFOs who will be prepared to certify financial statements. Management time will be spent on assessing internal controls and disclosing their effectiveness. A hidden cost of these and other provisions is a dramatic increase in insurance premiums. Gartner Inc. reports that "in early 2003, director and officer insurance premiums had exploded by $300 \%$ to $900 \%$ over 2001 levels. Professional liability insurance costs for accountants have risen similarly, increasing the cost of outside auditing services." FileNet Corporation, "Corporate Transparency: Addressing Sarbanes-Oxley in Today's Insurance Industry” (September 2003). However, see PriceWaterhouseCoopers, "Management Barometer: Sarbanes-Oxley Act Requires Changes in Corporate Control, Compliance" online <www.barometersurveys.com/production/barsurv.nsf/vwNewsDocsManagement/F88>, which states that there is some dispute about the compliance costs of SOX. AMR Survey cited in John Berlau "SarbanesOxley is Business Disaster" Insight on the News online at <www.insightmag.com/news/2004/02/03/National/SarbanesOxley.Is.Business.Disaster>; Gertner Inc. "Compliance with the Sarbanes-Oxley Act Requires Real-Time Data" cited in FileNet.

23 SOX, supra note 22 at $\$ 404$.

24 Under a voluntary system, firms may have to incur the costs of monitoring a developing legal system and ensuring that their governance structures and disclosure comply with the existing legal regime. It is true that the market may demand equally costly measures but as long as these are not legally required, they do not fall under the 
Second are the state's enforcement costs. Without question in any regulatory system enforcement costs can be significant. For example, in a recent study, Charles River Associates found that approximately $30 \%$ of the SEC's budget is spent on enforcement. ${ }^{25}$ If a purely voluntary code is in place, the state will bear policy design and implementation costs, as it does under a purely mandatory system. However, enforcement and market surveillance costs will not be as high. It is true that the regulator would still have a role in ensuring that firms are making full, true and plain disclosure of all material facts in respect of certain documents such as the prospectus. ${ }^{26}$ However, where there is no requirement for implementing governance practices and no corresponding remedy for failure to implement governance practices per se, the enforcement costs will be less than if the requirement and accompanying remedy existed.

Overall, the costs to issuers of a voluntary regime are likely less than the costs of a mandatory system, mainly because of reduced compliance costs. The advantages of a mandatory system are the establishment of minimum standards, enhanced compliance, and reduced information costs for investors. Certainly, these can also be advantages under a voluntary system. For example, information costs can be relatively low for investors where there is a recommended list of best practices in existence. In this case, the voluntary code can serve the same function as a standard form legal instrument by setting out what regulatory authorities will consider to be minimum standards for "good behaviour".

Even under a mandatory system, compliance is not guaranteed, since firms may not be motivated by fear of the penalties for non-compliance. Rather, they may simply ignore the law and absorb the costs of non-compliance. If the firm is performing well, investors will be pleased

common understanding of the term "mandatory" and the definition of the term used here. See above in "Introduction".

25 Charles River Associates, "Securities Enforcement in Canada: The Effect of Multiple Regulators", in Wise Persons' Committee - Committee to Review the Structure of Securities Regulation in Canada: Research Studies, (Ottawa: Wise Persons' Committee, 2003) 455 at 474 (A. Douglas Harris, ed.), at <http://www.wiseaverties.ca/reports/WPC_10.pdf> [the "Report"]. By contrast, of the four largest securities regulators in Canada, Alberta, Quebec, and Ontario all allocate between 15\% and 20\% of their budget to enforcement, while British Columbia allocates $13-14 \%$ of its budget to enforcement. In 2002, the actual enforcement budgets for these securities regulators were as follows (in Canadian currency): Alberta - \$3.084 million; Quebec - \$4.418 million; Ontario - \$9.225 million; British Columbia - \$3.456 million. The actual data for the SEC budget were not available. See The Report at 468-469 and 473.

26 Section 56, Securities Act (Ontario) R.S.O. 1990, c. S.5. 
with the stock price, and deviations from corporate governance standards will likely be of secondary importance to them. Unless the penalty is strict - such as an order cease trading the firm's stock - non-compliance is a real option for firms that are performing well.

It should be noted, however, that certain enforcement penalties can ultimately harm investors. A firm that is under investigation will likely experience a decreased share price once the investigation is disclosed. A firm that is cease-traded also ceases to be a viable investment. While enforcement may be considered an advantage for investors in terms of the protections they receive against corporate governance abuses, investors may in fact suffer from the penalties that are intended to protect them. This is certainly a disadvantage of the mandatory structure.

A further difficulty with these structures is that they have occasioned a proliferation of regulation in corporate governance and other areas. The state and its regulatory offshoots are concerned about ensuring that particular events (such as off-balance-sheet transactions, made familiar in the Enron debacle) do not occur. The state therefore passes new law to address the particular abuse, or even potential abuse, identified. The problem is that every event, even every major event, does not necessarily warrant its own new set of laws because existing laws are often sufficient to address the targeted abuse. Regulation, especially regulation that is redundant, repels issuers because it is costly. Since issuers are free to raise capital in a variety of markets worldwide, may avoid those markets that impose comparatively costly regulation. In particular, though these is no hard data on the effect of Sarbanes-Oxley on cross-listing, there is anecdotal evidence that foreign firms are less willing to list in the United States after the implementation of Sarbanes-Oxley because of its extension to cross-listed firms with certain exceptions. ${ }^{27}$

e. Flexibility

A main feature of voluntary regimes is their flexibility for issuers. Capital markets are populated by business entities of different sizes and types. As a result, different entities will prefer governance regimes that suit their own individual characteristics. For example, a rule that every company must have a nominating committee composed of independent directors might be

27 See discussion in Larry E. Ribstein, “Cross-listing and Regulatory Competition” (Sept 10, 2004$)$ at 26. 
onerous for a relatively small company with a small board of directors and a relatively small shareholder base. But for a large company with a sizable board, a nominating committee with mandated composition is less onerous. Flexibility in design of a firm's corporate governance practices is important and needs to be considered in terms of what is meaningful in light of the size of the firm and its board.

No doubt firms will seek to establish an efficient governance regime. This does not mean that they will not adopt any governance measures; rather, they will allow the market to dictate governance practices as necessary. They will be driven by investor demand, and perhaps pressure from their competitors, rather than by prescribed legal rules. This is one of the reasons why regulators must focus not only on investor protection but also on the efficiency that can be achieved by regulation that is cost-effective. Regulators must ask questions such as these: What legal rules enable firms to raise the highest amount of capital at the lowest cost? What legal rules permit the firm to operate at the lowest cost possible? Thus, flexibility in a corporate governance regime is important for both firms and regulators, both of whom have an interest in a regime which is cost-effective.

Mandatory regimes are inflexible. The state establishes not only the objective to be achieved but also the means to achieve the objective. For example, if the state seeks to protect investors, it may determine that the means to this end include increasing the number of independent directors on the board, forcing CEOs and CFOs to sign the financial statements, and ensuring that every member of the audit committee is financially literate. Firms that are targeted by the rules have limited choice regarding the content of rules and the means of compliance. ${ }^{28}$ Mandatory legislation, of which the Sarbanes-Oxley Act in the United States is the prime example, often does not differentiate among firms, making the regime even less flexible. ${ }^{29}$ For

\footnotetext{
28 Admittedly, some regimes allow a comment period for proposed instruments. See e.g. the rule-making procedure in Ontario under the Securities Act, R.S.O. 1990, c. S.5, as amended, § 143.2(10). The SEC has a similar procedure under which rule proposals are presented for comments from the public for a period of usually 30 to 60 days. See SEC, The Investor's Advocate: How the SEC Protects Investors and Maintains Market Integrity, at $<$ http://www.sec.gov/about/whatwedo.shtml>.

29 SEC rules promulgated under SOX do differentiate among firms to a minor extent. For example, accelerated deadlines for filing quarterly and annual reports apply only to companies that, inter alia, "have a public float of at least \$75 million.” See Press Release, SEC, “Commission Approves Rules Implementing Provisions of SarbanesOxley Act, Accelerating Periodic Filings, and Other Measures” (Aug. 27, 2002) at <http://www.sec.gov/news/press/2002-128.htm>.
} 
example, imagine mandatory legislation that does not differentiate between small, closely-held issuers and large, widely-held firms. The small cap or closely-held issuer might find a requirement to have a certain percentage of independent directors on their board or audit committee onerous since there may only be a few directors on the board to begin with. Corporate governance requirements designed for widely-held companies can create excessive costs for closely-held firms and small cap issuers.

Furthermore, compliance in a voluntary system may increase over time, leading to the clustering effect of voluntary firm behavior. In year one of a voluntary regime, relatively few firms may comply with the voluntary code. Over time, however, more and more firms may comply, believing that they will be "outdone" by their competitors if they do not. Thus compliance in the voluntary regime increases in year two and can continue to do so thereafter. The clustering effect is a pure market mechanism that can occur without the presence of legal rules.

It was mentioned above that one of the advantages of a command-and-control structure is that it mandates compliance. However, even under a mandatory structure, firms may choose to absorb the costs of their non-compliance rather than comply with the law. Such non-compliance renders the command-and-control structure ineffective and raises questions about the incentives underlying that structure. Of course, a firm's decision to absorb the costs of non-compliance will relate to the type of penalties that occur on breach, as well as to the extent to which those penalties are enforced. If legal penalties are low or enforcement is expected to be lax, then noncompliance is a viable option. Practically speaking, enforcement has been a weak link in the chain in capital markets scandals in Canada and, to a lesser extent, in the United States. ${ }^{30}$ While this fact compels us to rethink whether capital markets regulation should be based on a command-and-control structure, it says little about the preferred structure of corporate governance regulation specifically.

30 David Brown, "Corporate Governance: An Opportunity for Positive Change" (Remarks to the CFO Summit, June 21, 2004) at http://www.osc.gov.on.ca/About/Speeches/sp_20040621_db-corpgovernance.pdf. 
In short, from the firm's perspective, mandatory regimes are costly and inflexible while voluntary regimes are less costly and more flexible. It is likely the case that investors (and regulators in the name of investors) may have a bias in favour of mandatory regimes because these establish a baseline of consistent rules by which issuers must abide. This consistency and the possibility of enforcement provide comfort often referred to as "market confidence," to investors. However, implementing laws to protect investors often means increased costs for issuers, undermining the efficiency with which their businesses operate. It will be the shareholder who ultimately bears the cost of increased regulation. Furthermore, the effectiveness of penalties under a mandatory regime is questionable. For example, from a corporate standpoint, mere fines will be analyzed as a "cost" like any other and may therefore be ineffective at altering behaviour in any case. Thus, if a less rigid regime can achieve an equivalent level of investor protection at lower costs to issuers, this alternative should surely be explored.

\section{Incentives for Voluntary Behavior}

One way to maintain a high level of investor protection without creating excessive costs to issuers is to take advantage of firms' incentives to adopt recommended corporate governance practices, such as those contained in a list of best practices, voluntarily. But if we are to favor a voluntary structure of corporate governance, we must be certain that these incentives exist . What are the reasons that a firm would adopt corporate governance practices in the absence of a legal requirement to do so? In this section, we will see that there are both incentives and disincentives to adopt corporate governance practices voluntarily and to disclose whether these practices have been adopted. Without question, firms will assess the costs and benefits of a proposed course of action and will adopt practices that result in net benefits to them. ${ }^{31}$

This section will examine firms' incentives for voluntary behavior by building on two distinct bodies of literature within the broad topic of voluntarism. Some of the academic literature on voluntary behavior, particularly in the environmental area, analyzes the willingness of firms to adopt codes of behavior voluntarily in order to combat pollution and other environmental crises.

31 See Gray \& Roberts, supra note 1 at 118; Lauren Kelly, "The Development of a Positive Theory of Corporate Management's Role in External Financial Reporting” (1983) 2 J. ACCT. LITERATURE 111. 
This literature is relevant but of limited use, since the voluntary actions discussed tend to relate to codes agreed to by individuals and organizations rather than to guidelines set down by regulators and other lawmakers. ${ }^{32}$ By contrast, in this article, we are primarily examining voluntary codes established by the governing authority rather than about negotiated bilateral agreements among firms. Other literature deals with incentives to disclose information. This literature is also relevant but does not exhaustively address the topic, since we are speaking here of incentives to adopt governance practices in addition to obligations to disclose (e.g., ensuring that board members are financially literate). We will incorporate the relevant aspects of these bodies of literature in the discussion below.

\section{a. Incentives to Adopt Corporate Governance Practices Voluntarily}

This section discusses a variety of incentives that firms have to comply voluntarily with corporate governance practices, including deterring investors from devaluing the firm and preempting government regulation. The starting point for the discussion is to recognize that firms have a strong incentive to institute corporate governance practices voluntarily in order to deter or prevent investors from devaluing the firm. A firm's management or board may believe that if they fail to adopt corporate governance practices, investors will take their money elsewhere, especially if other firms are readily adopting these practices. It may be that the expected cost of investors discounting the value of the firm is so high that the firm is better served by incurring the costs of adopting the corporate governance practices. ${ }^{33}$

Whether investors actually discount the value of the firm if it has not adopted corporate governance practices depends, to some degree, on the content of the voluntary guidelines compared to the actual practices that a firm has adopted. While there appear to be no data yet on the propensity of firms to adopt corporate governance practices voluntarily, ${ }^{34}$ data relating to the

32 See Kernaghan Webb, "Understanding the Voluntary Codes Phenomenon" in VolUNTARY CodES: PRIVATE GOVERNANCE, THE PUBLIC INTEREST AND INNOVATION (Kernaghan Webb ed., 2003) 11.

33 Verrecchia makes a similar argument relating to firms' incentive to disclose information. See Verrecchia, "Discretionary Disclosure" supra note 1.

34 The author is currently conducting research in this area. See Anita I. Anand, Frank Milne \& Lynnette Purda, "Mandatory Versus Voluntary Corporate Governance: Examining the Impact of Sarbanes-Oxley on Foreign Firms" August 2004 (on file with the author). 
importance of corporate governance to investors have been studied and are certainly relevant. ${ }^{35}$ For example, Gompers, Ishii and Metrick have constructed a governance index and surveyed 1,500 firms' performance over the last decade. On the basis of these data, they argue that firms with stronger shareholder rights had higher firm value, higher profits, higher sales growth, and lower capital expenditures. ${ }^{36}$ This study does not prove a causal link between the value of the firm and its governance practices, but it does suggest that the two are correlated. In the competition for scarce capital, firms will seek to attract investors, and, since investors generally value good corporate governance, firms have a major incentive to adopt enhanced governance practices. $^{37}$

Another incentive for voluntary behaviour stems perhaps from a firm's desire to pre-empt government regulation by adopting certain practices in advance of a legal rule compelling them to do so. ${ }^{38}$ In the environmental area, for example, some empirical analysis has been conducted in the context of voluntary adoption of cleaner products or processes. ${ }^{39}$ Several studies show that a threat of mandatory environmental regulation can be one reason behind a firm's decision to reduce its pollution levels. ${ }^{40}$ This research suggests that firms voluntarily undertake "selfregulation" prior to the onset of mandatory regulation ${ }^{41}$ as way to forestall the more costly mandatory regulation. If firms have advance warning that legislative change may occur, they will

35 Gompers, Ishii and Metrick, supra note 3.

$36 \mathrm{Ibid}$. at 119-120 and 128-129. Another indicator that investors value a firm's governance regime is the increase in shareholder interest in governance issues. For example, the Canadian Coalition for Good Governance (CCGG) was formed in 2002 to fight for improved governance in Canadian companies. Full members of the CCGG manage, in aggregate, over half a trillion dollars in assets of Canadian corporations. See CANADIAN COALITION FOR GOOD GOVERNANCE, 2004 ANNUAL REPORT 2 (2004), at

<http://www.ccgg.ca/web/website.nsf/web/ccggnewsroom>. The objectives of the CCGG include ensuring that all public companies have highly qualified boards, ethical management, independent committees of the board, and compensation schemes that reward employees for superior work:

<http://www.ccgg.ca/web/website.nsf/web/ccgghome> ("mission statement"). Members of the CCGG include the Ontario Teachers Pension Plan Board (OTPPB), the Ontario Municipal Employees Retirement System (OMERS), Manulife Financial, Burgundy Asset Management, and Jarislowsky Fraser.

37 Note also the phenomenon of socially responsible investing, in which investors screen companies for good governance. One of the reasons they do this is to allow for meaningful shareholder participation. See <http://www.socialfunds.com/news/article.cgi/article916.html> and <http://www.mjrajsi.com/whatis_sri.asp?section $=5 \&$ level_2 $=23 \&$ level_3 $=0$ ) >.

38 Maxwell, Lyon \& Hackett, supra note 2 at 613.

39 Khanna \& Damon, supra note 2 at 2.

$40 \quad$ Ibid.

41 Maxwell, Lyon \& Hackett, supra note 2 at 584. 
commit to a certain level of self-regulation so that subsequent regulatory initiatives may be weakened or made unnecessary.

With respect to certain governance issues, we have seen anecdotal evidence of firms' attempting to deflect government regulation by exercising leadership in corporate governance. A number of firms in Canada (e.g., TD Bank) and the United States (e.g., Microsoft, Coca Cola) voluntarily decided to adopt the practice of expensing stock options. This practice may ultimately become a requirement under Generally Accepted Accounting Principles (GAAP), but it has also altered firms' business practices. Microsoft recently eliminated its stock option scheme in favor of giving shares to employees. A number of firms in Canada and the United States have also chosen to separate the CEO from the Chair of the Board function in the absence of a legal requirement to do so.

While firms no doubt recognize that they can benefit from adopting governance practices, such measures can be costly, as discussed above. But under a voluntary system, firms can determine the governance costs they are willing to absorb. A firm may decide not to implement certain governance measures, particularly if the firm is under-performing and the measures are costly. Funds spent on governance reform may, in management's view, be better allocated elsewhere. The issue is one of opportunity cost. Arguably, firms, not regulators, are best equipped to make decisions about whether spending a firm's capital on implementing governance measures should trump other capital expenditures that the firm needs to make. ${ }^{42}$

The assumption here has been the investors are always concerned that the firms in which they invest have comprehensive governance structure. However, it is not the case that investors are always concerned about good corporate governance. If the firm's share price is high and the firm has been performing well, investors will likely see no need to second-guess its governance structure. In other words, skeptcism about a firm's governance practices and the accompanying devaluing of the firm are less likely to arise when the return on equity is high. Ultimately,

42 It is true that it is managers who make these decisions and conflicts exist between their interests and their firms' interests. It is necessary, therefore, to contemplate the impact of agency costs on governance. As I will suggest below, mandatory disclose has the effect of reducing agency costs. Because disclosure of any negative 
shareholders care about value maximization: If value is high, then the firm's governance is of secondary importance.

\section{b. Incentives to Disclose Information Voluntarily}

Corporate governance practices consist of such actions as increasing the number of independent directors on the board and enhancing the financial literacy of members of the audit committee. But corporate governance also concerns the disclosure of this information to the investing public. As we will see, incentives to make disclosure voluntarily are not entirely similar to incentives to adopt corporate governance practices. To be clear, the term "disclosure," as used here, refers to economic and non-economic data, including data relating to the firm's governance structure. Such information is typically found in the firm's annual report in Canada and on Form $10-\mathrm{K}^{43}$ in the United States, but may also be found in the proxy circular and annual information form. $^{44}$

On a general level, firms' desire to deter investors from devaluing them provides an important incentive to disclose information voluntarily. Managers may believe that if they withhold information, investors are likely to conclude that the information is bad news. This is the "no news is bad news" hypothesis. ${ }^{45}$ Withholding information increases market "noise" because of the range of possible interpretations of the information. As a result, the expected cost of investors' discounting the value of the firm is so high that the manager is better served by making disclosure. ${ }^{46}$ Thus, disclosure assists in preventing devaluation of the firm by the market.

practices may hurt the company as a whole, directors, managers and other agents have less incentive to act contrary to the firms' interests.

43 See New York Stock Exchange, Listed Company MAnual § 303A Corporate Governance Rules (2003), at <http://www.nyse.com/pdfs/finalcorpgovrules.pdf> [hereinafter NYSE Rules].

44 See TSX COMPANY MANUAL, supra note 5 at $\$ 473$, which requires that companies include a "Statement of Corporate Governance Practices" in their annual report or information circular each year. MI 58-101, supra note 6, will require companies to disclose their corporate governance practices in their Annual Information Forms (AIFs). Some Canadian companies, in anticipation of MI 58-101, have already begun providing corporate governance disclosure in their AIFs.

45 Stephen A. Ross, "Disclosure Regulation in Financial Markets: Implications of Modern Finance Theory and Signaling Theory” in ISSUES IN FINANCIAL REGULATION: REGULATION OF AMERICAN BUSINESS AND INDUSTRY PINPOINT (F.R. Edwards ed., 1979).

46 Verrecchia, "Discretionary Disclosure" supra note 1 at 182. 
But would investors discount the value of a firm if they do not have information about its governance structure? Investors may consider no news about corporate governance to be bad news in terms of the governance structure that the firm has adopted - few independent directors, no separation of Chair and CEO, audit committee comprised of non-independent directors, and so on. In addition, no news about corporate governance would be bad news if the firm has historically been the subject of inquiry relating to its governance practices (for example, does the firm have a non-independent board about which shareholders have complained?). In addition, no news may be bad news if the firm has tended not to disclose its internal developments, such as granting stock incentives to members of management, to the market.

Notwithstanding these possibilities, it is reasonable to assert that investors will not always discount the value of the firm if they do not have information about its corporate governance practices. Investor skepticism will depend on many factors: the disclosure history of the firm and the firm's performance, including its share price for example. If the return on equity is high, investors will have much less incentive to analyze and evaluate the firm's governance structure. If the firm is under-performing, analysts and investors will search for reasons why this may be so. Such inquiries may lead them to conclude that the firm has a weak governance structure and indeed that the firm's performance may experience a turnaround if its governance structure were enhanced.

Given the profit-making objective, firms respond to investors' desire for information for reasons relating to the firm's business rather than for altruistic purposes. ${ }^{47}$ Investors are primarily concerned with obtaining information in purchasing securities and maintaining their investment portfolios, at least in theory. ${ }^{48}$ Management understands this information requirement and will disclose information if they believe that investors require it prior to making the decision to invest

47 See e.g. Diamond \& Verrecchia, "Disclosure, Liquidity and the Cost of Capital" supra note 1.

48 See Roberta Romano, "Empowering Investors: A Market Approach to Securities Regulation" (1998) 107 Yale Law Journal 2359. I use the term "in theory" here because of the investor apathy dilemma. See Frank H. Easterbrook \& Daniel R. Fischel, "Voting in Corporate Law" (1983) 26 J. L. \& ECON. 395 at 402; Martin Lipton, "Corporate Governance in the Age of Finance Corporatism" (1987) 136 U. PA. L. REV. 1 at 66-67; George W. Dent, Jr., "Toward Unifying Ownership and Control in the Public Corporation" (1989) WIS. L. REV. 881; Black, supra note 15 at 567-70; Stephen M. Bainbridge, "Independence Directors and the ALI Corporate Governance Project" (1993) 61 GEO. WASH. L. REV. 1034 at 1055. 
or remain invested. Thus, the competition for capital among firms determines the optimal level of disclosure. $^{49}$

Thus far, we have discussed on a general level firms' willingness to make disclosure in the absence of a legal requirement to do so. Does our thinking about incentives change when we consider a mandatory disclosure regime of corporate governance best practices specifically? Without question, requiring disclosure of compliance with best practices provides an incentive to comply with voluntary guidelines, since firms are revealing their internal structure and compliance or non-compliance with the voluntary code. This information can certainly repel investors if negative. On the other hand, this information can encourage competition amongst firms to adopt similar reforms.

While firms no doubt recognize that they can benefit from making disclosures about corporate governance, such disclosures can be costly. These costs create disincentives to disclosure. For example, pre-dissemination costs associated with disclosure include the cost of gathering, organizing, and preparing the information. If a firm is not certain of the requirements embedded in the legal regime, such as the information it may disclose, additional costs can arise from having to hire legal experts to advise the firm with respect to its obligations under applicable law. Further costs arise in disseminating the information and can include mailing to shareholders and other market participants as well as press releases, website updates, and analyst conferences.

Certain other costs affect firms that disclose information. There are costs associated with updating and revising disclosure as well as keeping current with legal developments. There are other costs that arise post-dissemination, primarily from the consequences of the disclosure made. An example of such a cost is a "proprietary cost," which is, broadly speaking, a cost associated with disclosing information that arises from any potentially damaging action on the part of the firm. ${ }^{50}$ Proprietary costs arise, for example, when a firm issues unfavorable information and a bank thereafter asks for its loan to be repaid. ${ }^{51}$ In the corporate governance context, proprietary

49 See Diamond \& Verrecchia, "Disclosure, Liquidity and the Cost of Capital" supra note 1.

$50 \quad$ Verrecchia, "Discretionary Disclosure" supra note 1 at 181.

$51 \quad$ Ibid. 
costs could conceivably also arise if a firm disclosed that one of its audit committee members was not financially literate and, as a result, the firm was subjected to greater scrutiny by rating agencies and lenders. Other post-dissemination costs arise if the disclosure contains an error that the firm corrects ex post in the form of more disclosure. The cost results when shareholders sell their shares because of the disclosure and the firm's stock price subsequently decreases.

But are there costs that arise if the disclosure is made purely on a voluntary basis rather than because of the existence of a particular law? Voluntary disclosures can also create competitive disadvantages for the firm. This is yet another type of proprietary cost. ${ }^{52}$ Firms will be reluctant to disclose information from which their competitors can benefit. If a firm's rivals can use voluntary disclosure to become more competitive, the benefits of the disclosure are reduced. ${ }^{53}$ In their interviews with British multinationals, for example, Gray and Roberts discovered that disclosures especially sensitive to the costs of competitive disadvantage include future-oriented financial information that quantifies forecasts of sales and profits, as well as information relating to sales and profits in narrowly defined geographical or business areas. ${ }^{54}$

A firm's competitors may specifically seek and use information about its governance practices. Arguably, information about a firm's governance structure is not akin to sensitive information such as a breakdown of the corporation's financials, projected financial data, or sales figures for a specific product line or service; information about governance is in the category of "process" or "administration," whereas certain other information can be used by competitors to gain an advantage over the disclosing firm. However, the more a company discloses about its implementation of internal controls in its attempts to be a good corporate actor, the more information is available to other companies, at little to no cost. Thus, competitors may gain a competitive advantage from the disclosure of information regarding their competitors' governance practices. ${ }^{55}$

52 Ibid. See also Réal Labelle, "The Statement of Corporate Governance Practices (SCGP), A Voluntary Disclosure and Corporate Governance Perspective" (June 2002) at $\langle$ http://ssrn.com/abstract=317519 $>$ at 10.

$53 \quad$ Verrecchia, "Discretionary Disclosure" supra note 1 at 182.

$54 \quad$ Gray \& Roberts, supra note 1 at 126.

$55 \quad$ Labelle, supra note 52 at 10. 
These disincentives to voluntarily disclose information about corporate governance practices are strong. They will be stronger if a firm has bad news relating to its governance practices to report than if it has positive information. ${ }^{56}$ This suggests a significant bias in information disclosed under a voluntary disclosure regime. But even if a firm has good news relating to its governance, it may be reluctant to disclose it since enhanced transparency will leave firms open to potential criticism by the market for the structure that it has chosen.

Without question, firms will assess the costs and benefits of possible disclosures and will voluntarily disclose information that is likely to result in the highest net benefit to the firm. ${ }^{57}$ The costs and benefits will vary depending on the particular pressure giving rise to the perceived need for disclosure, as well as on the particular information being disclosed. But given the disincentives for voluntary disclosure, it seems necessary to consider the potential usefulness of a mandatory disclosure regime in the corporate governance context.

\section{Implications for Devising a Legal Regime}

The previous section argued that firms will voluntarily adopt governance practices and disclose their adoption of such practices if the net benefits of doing so exceed the costs. This section takes the examination one step further by analyzing the policy implications of recognizing that firms have incentives to engage in voluntary behavior. The discussion is divided into three parts: a survey of four jurisdictions' governance regimes; analyses of different types of governance regimes with a view to choosing an optimal regime; and flexibility as a component of optimality. The argument is that, since firms have incentives to adopt healthy governance practices voluntarily, the state should take advantage of these incentives to create a governance regime that is less costly for firms and still protects investors. If firms are prepared to adopt more comprehensive corporate governance practices voluntarily, and we have seen that they have incentives to do so, then implementing a legal regime that compels them to adopt such practices is unnecessary. The optimal governance structure is a partially mandatory regime in which compliance with a code of governance practices is voluntary but disclosure regarding the extent

$56 \quad$ Gray \& Roberts, supra note 1 at 118.

$57 \quad$ Gray \& Roberts, supra note 1 at 118. See also Kelly, supra note 31. 
of such compliance is mandatory. This regime is optimal because its costs are less than its benefits and because it provides virtually the same benefits as a mandatory structure at a lower cost.

\section{a. Comparative Analysis by Jurisdiction}

We begin the discussion by examining the governance structures in four major common law jurisdictions. We will see that while the United States has a mandatory structure, Canada, the United Kingdom, and Australia all have partially mandatory corporate governance regimes. The latter jurisdictions have all adopted a "comply and explain" system in which they recommend compliance with "best practice" guidelines. While compliance with these guidelines is voluntary, disclosure regarding compliance is not. By law, firms must make certain disclosure regarding the extent to which they have complied with best practice guidelines. Once we discuss the regimes in Canada, the United Kingdom, and Australia, we will compare them to the U.S. system.

In Canada in 1995, the Toronto Stock Exchange (TSX) issued a list of best practices that firms may follow, but they are not obliged to do so. ${ }^{58}$ The TSX best practice guidelines address the following corporate governance issues: the board's mandate; its composition (including minority shareholder representation); board committees; board approval; structures in place to facilitate an independent board; procedures for recruiting new directors and assessing board performance; measures for receiving shareholder feedback; and the board's expectations of management. These nine requirements reflect previous recommendations regarding the minimum content of disclosure to be made by affected companies. ${ }^{59}$

Added to the best practice guidelines is a disclosure requirement. Disclosure regarding the extent of a firm's compliance with the best practices is required in a "Statement of Corporate

58 The guidelines emanated from the Dey Report, supra note 8. The TSX adopted the Dey Report in February 1995 and on May 3, 1995, released TSE By-Law 19.17, which requires companies incorporated in a Canadian jurisdiction and listed on the Exchange to make disclosure annually regarding their corporate governance practices in an annual report or information circular. These guidelines came into effect beginning with companies whose fiscal year ended on June 30, 1995. See Carol Hansell, "The Dey Report. Background and Compliance with the TSE and ME Disclosure Requirements", in COMPLYING WITH THE TSE REPORT ON CORPORATE GOVERNANCE. CONTINUING LEGAL EDUCATION HELD TUESDAY, JANUARY 9, 1996, at 14, Schedule B (Canadian Bar Association - Ontario ed., 1996). See also TSX COMPANY MANUAL, supra note 5 at $\S 472$. 
Governance Practices" in the firm's proxy circular or annual report. ${ }^{60}$ A listed company must make disclosure with reference to the guidelines and where its governance system differs from the guidelines, it must explain the differences. ${ }^{61}$ Initially, it was unclear, what explanation of the differences was required - whether, for example, a mere listing of the differences from the best practice guidelines was sufficient, or whether a justification for each difference (and the extent of the difference) was necessary. ${ }^{62}$ The TSX attempted to clarify its requirements with later directives and amendments, ${ }^{63}$ but the continuing ambiguity is still evident from the variety of forms of disclosure that different companies continue to produce.

In 2003, two events occurred that changed the nature of this regime. First, the TSX announced that it would pass authority over corporate governance matters to the Ontario Securities Commission (OSC), the regulator of Canada's largest capital market. ${ }^{64}$ This transfer seemed natural, since the OSC is the primary regulator of capital markets in Ontario, while the TSX is a self-regulatory organization operating under OSC oversight. However, the transition is still occurring, and the TSX structure remains largely in place. ${ }^{65}$ Second, the OSC was granted authority from the provincial government to make rules relating to audit committees. ${ }^{66}$ The OSC subsequently issued regulations mandating audit committee composition and certification of

\footnotetext{
$59 \quad$ Dey Report, supra note 8 at II 8.1.

60 TSX COMPANY MANUAL, supra note 5 at $\S 473$.

61 The TSX Company Manual, supra note 5 at $\S 473$, states that "where the company's system is different from any of those guidelines or where the guidelines do not apply to the company's system, an explanation of the differences or their inapplicability" must be made in the company's Statement of Corporate Governance Practices. Section 474 lists the fourteen recommendations of the Dey Committee.

$62 \quad$ Hansell, supra note 58 at 18.

63 See letter from Clare Gaudet, supra note 21.

64 See Karen Howlett “TSX No Longer Governance Cop” THE GLOBE \& MAIL (20 September 2003). Until MI 58-101 is adopted, the TSX retains some authority over corporate governance through the requirement of the Statement of Corporate Governance Practices, while the OSC has authority over audit committees pursuant to Multilateral Instrument 52-110: Audit Committees (2004), at <http://www.osc.gov.on.ca/Regulation/Rulemaking/Current/Part5/rule_20040326_52-110-audit comm.jsp> [hereinafter MI 52-110] and certification requirements pursuant to Multilateral Instrument 52-109: Certification of Disclosure in Issuers' Annual and Interim Filings (2004), at <http://www.osc.gov.on.ca/Regulation/Rulemaking/Current/Part5/rule_20040326_52-109-cert.jsp> [MI 52-109]. 65 See TSX, Summary of 2003 Toronto Stock Exchange Corporate Governance Disclosure Survey 3, at <www.tsx.com/en/pdf/TSXCorpGovSummary.pdf >: "The provincial securities commissions are contemplating new corporate governance rules. Until these come into effect, all companies listed on TSX must continue to disclose their corporate governance practices against the TSX guidelines." See also Howlett, supra note 64.

66 Bill 198, Act to implement budget measures and other initiatives of the Government, 3d. Sess., 37th Leg., Ontario, 2002, was passed in April, 2003. It enhances the rule-making powers of the OSC and contains enforcement provisions for the Ontario Securities Act.
} 
financial disclosure. ${ }^{67}$ However, most of the other features remained voluntary, as they had been under the TSX regime.

The OSC, as well its counterparts in the Canadian Securities Administrators, recently issued a voluntary code of best practices that is similar to and would replace the TSX governance guidelines. ${ }^{68}$ The disclosure element under the OSC's voluntary code continues to be mandatory, but it is more strict than under the TSX regime. Under the new regime, every issuer (i.e., both listed and unlisted) must disclose its corporate governance practices and whether or not it complies with the guidelines. Further explanation is required with respect to why the board considers non-compliance with the guidelines to be appropriate. Certain differences relating to disclosure are drawn between venture and non-venture issuers; the latter being subject to more stringent disclosure standards than the former. ${ }^{69}$

The U.K. regime is also a partially voluntary system under the 1998 Combined Code. ${ }^{70}$ The Code places more emphasis on remuneration issues than either the TSX or the OSC regime,

$67 \quad$ MI 52-110 and MI 52-109, supra note 64.

68 MI 58-101 would replace the TSX guidelines. Note that two aspects of the CSA's governance regime are indeed mandatory: the audit committee requirements under MI 52-110, supra note 64, and the certification requirements under MI 52-109, supra note 64.

69 A "venture issuer" is defined in MI 58-101, § 1.1 as "an issuer that does not have any of its securities listed or quoted on any of the Toronto Stock Exchange, a U.S. marketplace, or a marketplace outside of Canada and the United States of America." Both venture and non-venture issuers must disclose the text of the written mandate of their board. See Form 58-101F1, § 2 for non-venture issuers; Form 58-101F2, § 2 for venture issuers. If they do not have a written mandate, they must explain why the board considers this to be appropriate. Both must also disclose information regarding their code of business conduct and ethics (see Form 58-101F1, § 5 for non-venture issuers; Form 58-101F2, § 3 for venture issuers). However, non-venture issuers must also make disclosure regarding position descriptions and performance assessment (see Form 58-101F1, § 3); orientation and continuing education of directors (see Form 58-101F1, § 4); compensation of directors and the compensation committee (see Form 58-101F1, $\S 7$ ); and regular board assessments (see Form 58-101F1, § 8). Both Forms accompany MI 58-101 and are posted on the OSC website. See MI 58-101, supra note 6.

70 Committee on Corporate Governance, The Combined Code PRINCIPLes of GoOd Governance ANd Code OF BEST PRACTICE (1998) (Hampel, Chair), at <http://www.fsa.gov.uk/pubs/ukla/lr_comcode3.pdf>. Note that revisions to the Code occurred post-Enron and were put in place January 15, 2004. See Financial Services Authority, The Listing Rules (Combined Code) (Amendment) Instrument 2004, FSA 2004/16, at <http://www.fsa.gov.uk/handbook/legal_instruments/2004/2004_16.pdf>, which entered THE COMBINED CODE ON CORPORATE GOVERNANCE (July 2003), at <http://www.fsa.gov.uk/pubs/ukla/lr_comcode2003.pdf>, into force. The Combined Code applies only to companies incorporated in the United Kingdom. Rule 12.43A of the U.K.L.A. Listing Rules reads as follows:

In the case of a company incorporated in the United Kingdom, the following additional items must be included in its annual report and accounts:

(a) a narrative statement of how it has applied the principles set out in Section 1 of the Combined Code, providing an explanation which enables its shareholders to evaluate how the principles have been applied; 
and less emphasis on audit committees, but essentially creates best practice guidelines for the same general areas of governance. ${ }^{71}$ Compliance with these guidelines is voluntary. However, companies listed on the London Stock Exchange are required to include in their annual report a twe part disclosure statement. This statement explains how the companies apply the principles of the Combined Code ${ }^{72}$ and must either confirm that it complies with the provisions of the Code or explain why it does not comply. ${ }^{73}$ There is thus a substantial similarity between the U.K. and Canadian regimes, in that compliance is voluntary but disclosure is mandatory. However, whereas the Canadian regime does not create advantages for non-listed issuers, the U.K. regime does provide some leeway for them with flexible recommendations. ${ }^{74}$

Relative to the Canadian and U.K. regimes, the current corporate governance regime in Australia is quite new. It revolves around the Australia Stock Exchange (ASX) Corporate Governance Council's “Principles of Good Corporate Governance and Best Practices

(b)

a statement as to whether or not it has complied throughout the accounting period with the Code provisions set out in Section 1 of the Combined Code. A company that has not complied with the Code provisions, or complied with only some of the Code provisions or (in the case of provisions whose requirements are of a continuing nature) complied for only part of an accounting period, must specify the Code provisions with which it has not complied, and (where relevant) for what part of the period such non-compliance continued, and give reasons for any non-compliance....

For a discussion of the effect of the Combined Code on foreign listed companies, see Iain MacNeil \& Alex Lau, "International Corporate Regulation: Listing Rules and Overseas Companies" (2001) 50 INT'L \& COMP. L.Q. 787 at Part III.

71 The areas of governance covered in the 1998 Combined Code include board mandate; procedure for taking independent professional advice; board independence; director training; separation of CEO and chair of the board; senior independent director (similar to lead director); board composition; "non-executive" directors versus "independent" directors (similar to "independent" versus "unrelated"); nominating committee duties and composition; re-election of directors; directors' remuneration (including performance-related standards, shareoptions plans, terms of contracts, early termination impacts, procedures for developing executive and director remuneration, and disclosure and approval issues related to remuneration); communication with shareholders, institutional and private; use of the annual general meeting; responsibilities of directors and auditors in respect of reporting; internal control systems; internal audit function; audit committee mandate and composition; audit committee duties; and non-audit services. Although it adds only one new sub-heading ("Performance Evaluation" under the heading "Directors"), the 2003 Combined Code is more comprehensive than the 1998 Combined Code; it includes more broadly drawn principles and stronger code provisions. For example, the 2003 Combined Code gives more direction to non-executive directors regarding their role as scrutinizers of management and the integrity of financial information and controls; it recommends that non-executive directors meet without executives present; and it more strongly recommends the separation of the positions of CEO and the chair of the board.

72 This requirement is found in the Preamble of both versions of the Combined Code, at 9 If 4.

73 U.K.L.A. Listing Rules, supra note 70, Rule 12.43A(b).

74 Under s. A.3.2 of the Combined Code, it is recommended that smaller companies have at least two independent non-executive directors (rather than the recommendation that at least half of the board be non-executive directors [NEDs] for larger companies). Under s. C.3.1, it is recommended that smaller companies have at least two members of the audit committee who are NEDs (rather than the recommendation that at least three members be NEDs for larger companies). 
Recommendations." 75 Each company listed on the ASX is required to provide a corporate governance statement in its annual report. The ASX Guide presents ten core principles and includes guidance and recommendations on how to achieve best practice. ${ }^{76}$ These principles broadly correspond with the principles of Canadian regimes.

The ASX regime takes an "if not, why not?"77 approach to corporate governance disclosure. Unlike the TSX, OSC, and U.K. regimes, the ASX regime does not usually require disclosure of compliance; rather, it requires disclosure of non-compliance, with an explanation of why the company's board believes that non-compliance is appropriate. There are some instances where further disclosure - that is, an explanation of more than simply a departure from the best practice guidelines - is required. Specifically, more extended disclosure is required with respect to board structure, integrity in financial reporting, performance evaluation, and remuneration policies. Smaller companies receive no differential treatment under the regime. ${ }^{78}$

The systems in all these jurisdictions stand in stark contrast to the corporate governance regime in the United States which is largely mandatory. The current U.S. corporate governance regime is composed of both the Sarbanes-Oxley Act (SOX) and stock exchange requirements for listed companies. The mandatory elements in these structures are extensive. For example, under SOX, the following is required: certification by CEOs and CFOs of financial and other

75 ASX Corporate Governance Council, PrinciPles of GoOd CoRporate GovernanCE AND BeSt PRACTICE RECOMMENDATIONS (2003), at

<http://www.shareholder.com/visitors/dynamicdoc/document.cfm?documentid=364\&companyid=ASX> [hereinafter "ASX Guide"]. The ASX Guide's requirements come into effect for companies' first financial year commencing after January 1, 2003.

$76 \quad$ Ibid. at 3.

77 See ASX Guide at "Foreword"; Press Release, ASX, Corporate governance - Implementation Review Group delivers report (March 31, 2004) at <http://www.asx.com.au/about/pdf/CGCreview310304.pdf>.

78 See ASX Corporate Governance Council Implementation Review Group, Principles of Good Corporate Governance and Best Practice Recommendations: Report to the ASC Corporate Governance Council at 2 (March 31, 2004):

The [Implementation Review Group] received numerous submissions suggesting that particular classes of companies (e.g. small companies) should be exempt from the requirement to report against the Council's Recommendations. The IRG believes, however, that the 10 Principles and the requirement to report against the Recommendations should apply to all listed companies, regardless of size or maturity. Exempting any class of listed company from reporting against the Recommendations would be inconsistent with the disclosure-based approach.

Karen Leslie Hamilton of the ASX Corporate Governance Council wrote in the ASX Guide, ibid. at "Foreword," "The size, complexity and operations of companies differ, and so flexibility must be allowed in the structures adopted to optimise individual performance. That flexibility must, however, be tempered by accountability - the obligation to explain to investors why an alternative approach is adopted - the 'if not, why not?' obligation." 
information in companies' quarterly and annual reports; ${ }^{79}$ CEOs' and CFOs' reimbursement of bonuses for misconduct resulting in the issuance of a restatement of financial disclosure; ${ }^{80}$ disclosure of material off-balance transactions and non-GAAP accounting; ${ }^{81}$ disclosure of transactions by management, directors, and significant shareholders (shareholders holding 10\% or more of the shares in a company) $;^{82}$ management establishment and maintenance of internal control systems, assessment of the effectiveness of these controls by management, and attestation and assessment by external auditors in annual disclosure $; 3$ disclosure of whether the company has a code of ethics for senior financial officers, ${ }^{84}$ if not, why not, and any waivers of the code of ethics: ${ }^{85}$ and, lastly, disclosure of whether there is a financial expert on the audit committee and, if not, why not. ${ }^{86}$

It is true that the last two of these elements take the "if not, why not" approach of the Australian regime. However, their presence does not permit the U.S. regime to be classified as partially mandatory. The majority of elements of SOX, in conjunction with the elements of the NYSE Rules (to use an example ${ }^{87}$ ), certainly warrant referring to the U.S. regime as mandatory. The new rules recently added to the existing NYSE governance regime include majority of independent directors; ${ }^{88}$ disclosure of determinations of director independence ${ }^{89}$ regularly scheduled executive sessions of non-management directors of each company without management present; ${ }^{90}$ nominating committee/corporate governance committee and compensation committee, composed entirely of independent directors, ${ }^{91}$ with a written charter addressing each committee's purpose and responsibilities ${ }^{92}$ and an annual performance evaluation

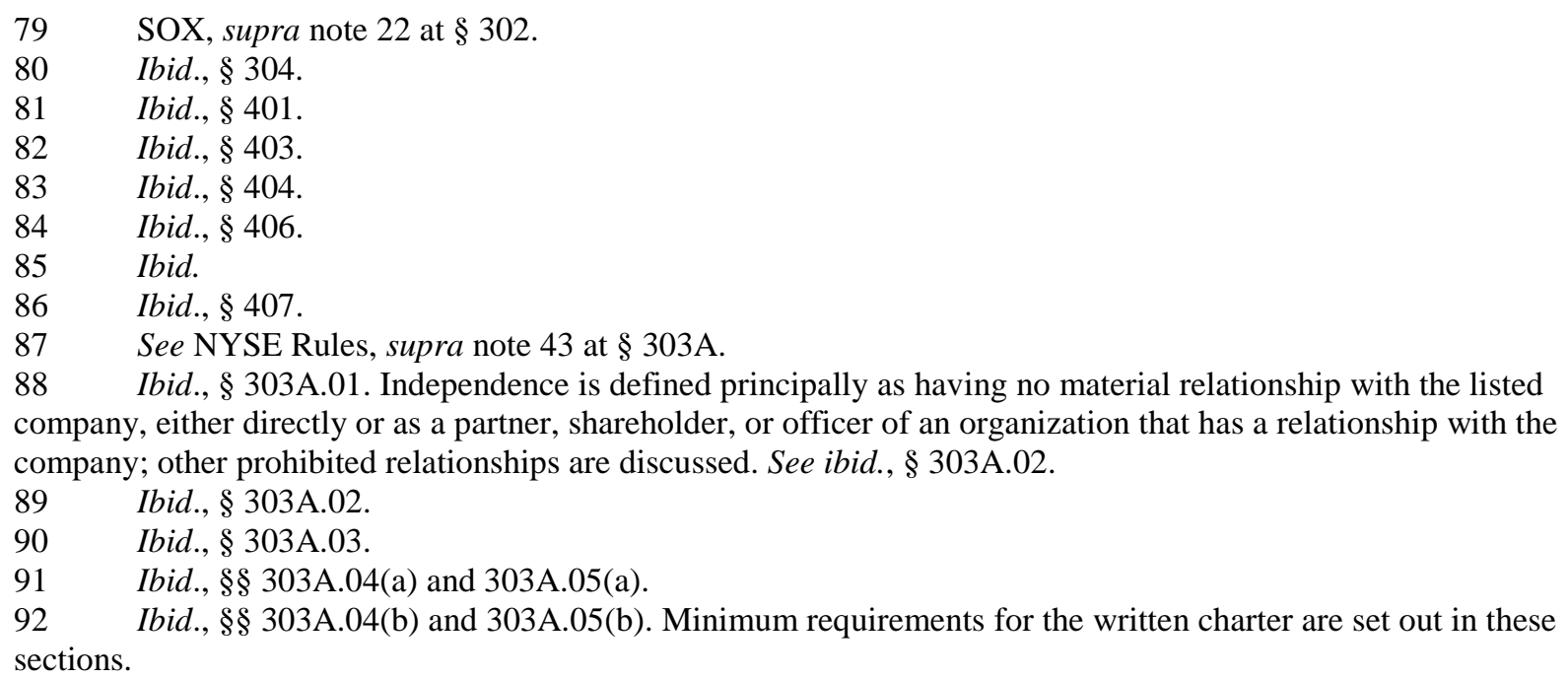


of the committee; ${ }^{93}$ audit committee that meets the requirements of Rule $10 \mathrm{~A}-3$ under the Exchange Act and has a minimum of three members $;{ }^{94}$ internal audit function; ${ }^{95}$ shareholder voting to approve equity compensation plans; $;{ }^{96}$ and adoption and disclosure of corporate governance guidelines ${ }^{97}$ and of a code of business conduct and ethics for directors, officers, and employees. ${ }^{98}$ Note that under the NYSE regime, there is no "if not, why not" disclosure provision. Rather, the provisions are mandatory. ${ }^{99}$

The SEC implemented partial exemptions from some of SOX requirements in response to criticisms from countries such as Germany and other countries that have different board structures than the United States. ${ }^{100}$ The SEC rule permits non-executive employees in foreign firms to serve as audit committee members, large shareholders to send observer representatives, and foreign firms to make substitutions for the audit committee. ${ }^{101}$ The SEC also clarified compliance for companies with two-tier boards as in Japan. ${ }^{102}$ These exceptions are limited and relate only to one of the various mandatory requirements of Sarbanes-Oxley. (In Canada the exceptions are not relevant because of the mandatory rule relating to audit committee composition discussed above.)

In sum, in three major common law jurisdictions outside the United States, the corporate governance regimes are partially mandatory. Indeed as part of this project, we examined the countries on the website of the European Commission Governance Institute. As noted in

\footnotetext{
93 Ibid., $\S \S 303$ A.04(b)(ii) and 303A.05(b)(ii).

$94 \quad$ Ibid., $\S 303$ A.06. Audit committee members must satisfy the requirements for independence, and the audit committee must have a written charter addressing its purpose (minimum purposes listed), an annual performance evaluation of the audit committee, and the duties and responsibilities of the audit committee. See ibid., § 303 A.07. 95 Ibid., § 303A.07(d).

$96 \quad$ Ibid., § 303A.08.

97 Ibid., § 303A.09.

$98 \quad$ Ibid., $\$ 303$ A.10. This section requires listed companies to disclose any waivers of the code of business conduct and ethics promptly.

99 The NYSE Rules do exempt the following types of firms from specific requirements: controlled companies; limited partnerships and companies in bankruptcy; closed-end and open-end funds; passive business organizations in the form of trusts; derivatives and special-purpose securities; and foreign private issuers. The exemptions from which these types of companies benefit usually reflect the already onerous requirements that they face from other regulators. See NYSE Rules, ibid., § 303A.

$100 \quad$ See Ribstein, supra note 27 at 26.

101 CFR Section 240.10A-3.

102 Ronald J.Gilson and Curtis J. Milhaupt, "Choice as Regulatory Reform: The Case of Japanese Corporate Governance" (Paper presented at the Law and Economics Workshop Series, The University of Toronto September $15,2004)$.
} 
Appendix 1, we found that of the 28 countries examined, 12 countries had a completely voluntary governance regime, 14 countries had a partially mandatory regime and one, possibly two, had a mandatory structure (the U.S. and Pakistan). ${ }^{103}$ In short, the U.S. mandatory regime is clearly not the structure that most countries have adopted. At least one reason for this regulatory difference among countries is that the mandatory regime occasions unnecessary costs; it does not take advantage of firms' incentives to adopt healthy governance practices voluntarily, and it does not allow firms flexibility in choosing governance practices that accord with their size, board structure etc. While there are variations among the structures in the common law jurisdictions analyzed above, all of them adopt some form of mandatory disclosure. The seeming popularity of the partially mandatory structure leads one to question why these jurisdictions have adopted a hybrid corporate governance regime and, in particular, what are the benefits of such a regime.

\section{b. Choosing a Governance Structure}

This section establishes a framework, and outlines particular considerations, which underpin an optimal governance regime. Central to the framework is an analysis of costs and benefits. If the costs of a corporate governance regime outweigh its benefits, then arguably the mandatory regime should not be in place. Specifically, the cost analysis can be completed by weighing the level of expected compliance against the aggregate costs of each type of regime. We will see that the benefits of a governance regime are relatively transparent, while the costs are not.

Governance reform: Benefits and Costs. A latent assumption in the academic literature is that there is a causal relationship between corporate governance and firm performance. ${ }^{104}$ However, U.S. and recent Canadian research belies this intuition. ${ }^{105}$ For example, Dalton et al.

\footnotetext{
103 See European Corporate Governance Institute http://www.ecgi.org/index.htm. For the list of member countries and the index of codes see http://www.ecgi.org/codes/all_codes.php. Only countries that had released a Code (or Draft Code) post the enactment of Sarbanes-Oxley were examined. Countries that had governance codes pre-dating Sarbanes-Oxley were not included although the author is currently examining these countries also. 104 For example, Anita I. Anand, "Shareholder Isolation and the Regulation of Auditors" (2004) 54 U. TORONTO L.J. 1.

105 See e.g. Jerilyn W. Coles, Victoria B. McWilliams \& Nilanjan Sen, “An Examination of the Relationship of Governance Mechanisms to Performance” (2002) 27 J. MGMT. 23; Henry L. Tosi, Jeffrey S. Katz \& Luis GomezMejia, "How Much Does Performance Matter? A Meta-Analysis of CEO Pay Studies" (2000) 26 J. MGMT. 301; John E. Core, Robert W. Holthausen \& David F. Larcker, "Corporate Governance, Chief Executive Officer
} 
have found little evidence to support any relationship between governance and performance. ${ }^{106}$ Coles et al. conclude that industry performance, rather than governance variables, explains individual firms' performance. ${ }^{107}$ Jog and Dutta provide Canadian evidence that the link between good governance and good performance "is so elusive that we would be better off searching for a unicorn.",108

While there is no causal link between good governance and firm performance, there is evidence of a positive correlation between the two. In particular, as noted above, Gompers et al. have found that during the 1990s, corporate governance was strongly correlated with stock returns. ${ }^{109}$ Gompers et al. admit that the evidence does not permit strong conclusions of causality, since it is possible that their results were driven by characteristics other than the governance index that they constructed. However, as they point out, the study suggests that differences in firm value may be caused by items on the governance index. This, in turn, highlights a link between corporate governance and firm performance that remains to be pursued in future research.

Nevertheless, given the empirical data, it is impossible to conclude definitively that one of the benefits of a comprehensive governance structure is heightened firm performance. Why, then, do regulators, investors, and public interest groups lobby for higher standards of corporate governance? Shareholders may view the issue a little differently. They may believe that bad governance is a sign of, or reason for, poor performance. Thus, enhanced governance may be one factor that could lead to better performance. There are other perceived benefits, including: greater accountability to investors by such mechanisms as an independent board, an independent and financially literate audit committee, and increased disclosure.

Compensation and Firm Performance" (2000) 51 J. Fin. 371; Anup Agrawal \& Charles Knoeber, "Firm Performance and Mechanisms to Control Agency Problems between Managers and Shareholders" (1996) 31 J. FIN. \& QuANTITATIVE ANALYSIS 377; Vijay Jog \& Shantanu Dutta, "Searching for the Governance Grail” (2004) CAN. INVESTMENT REV., at 33.

106 Dan R. Dalton et al., "Meta-Analytic Reviews of Board Composition, Leadership Structure, and Financial Performance" (1998) 19 Strategic MGMT. J. 269.

107 Coles, McWilliams \& Sen, supra note 105.

108 Jog \& Dutta, supra note 105.

109 Gompers, Ishii \& Metrick, supra note 3 at 124. 
Investors risk their capital when they make an investment in a company. From the investors' perspective, the risk of loss is great and the cost of good corporate governance is minimal, since instituting higher governance standards will likely have a negligible impact on the return on equity. On the positive side, an extensive corporate governance regime may prevent them from losing everything, as Enron's investors did. It may also protect investors from other scenarios in which decisions are made that are not in the investors' best interests, decisions that may not occasion massive losses but may affect the return on equity nonetheless.

In light of investor concerns, firms may believe that good corporate governance can also be good for business (in terms of attracting investors). Much will depend on whether other firms expand their governance regime and what "standard practice" becomes. ${ }^{110}$ Firms may decide to absorb the costs of heightened governance practices in order to compete with other firms for capital and to entice investors. They may also adopt practices that incur little or no real cost to the company.

While the benefits of a corporate governance regime are relatively transparent, the corresponding costs are not. A cost analysis can be completed by weighing the level of expected compliance against the aggregate costs of a particular regime (i.e., mandatory or voluntary). One can expect lower compliance in a voluntary regime than in a mandatory regime because there is no threat of enforcement penalties to underpin the rule. But one would also expect that the costs of a voluntary regime will be lower. Specifically, aggregate compliance costs will be lower because firms can opt out of measures that are excessively costly for them. They can tailor their governance structures to their particular firm characteristics (e.g., size and capital structure) and refrain from incurring enforcement costs, dissemination costs, and potentially higher compliance costs. Thus, the tradeoff is that there are lower costs in a voluntary structure but also lower compliance, while there are higher costs in a mandatory structure but higher compliance overall.

As noted in Part II, it is possible that compliance in a voluntary structure increases over time. While compliance with a voluntary code in year one may not be high, in year two it may

110 See discussion above, Part II, relating to firms' incentives to adopt corporate governance practices voluntarily and to disclose such practices voluntarily. 
increase if firms feel pressure from other market actors to adopt the same governance practices: Market forces occasion greater compliance. Admittedly, there is no guarantee that compliance will in fact increase, and it could certainly decrease, depending on market conditions. Furthermore, in the absence of disclosure, information asymmetry problems remain, with investors not knowing what governance structure the firm has in fact adopted.

A partially mandatory or hybrid structure is likely to yield a fairly high level of compliance at a lower cost than a wholly mandatory regime. There are two main permutations of a partially mandatory structure, both of which strike some arrangement between firms' adoption of corporate governance measures and their disclosure of such measures. Disclosure provides an incentive to comply, since firms are in essence broadcasting their internal structure and compliance, or non-compliance, with the guidelines or best practices. Under one alternative, the adoption of certain governance practices is mandatory but disclosure relating to the adoption is optional. In this scenario, the incentive to comply stems from the existence of a penalty for failure to comply. Undermining the incentive, however, is the fact that there is no disclosure requirement, and so "no one will know" whether the firm is complying.

Under a second alternative, the adoption of governance practices is optional but the disclosure is mandatory. In this scenario, firms have flexibility in designing their individual governance regimes. A flexible governance structure is necessary to account for differences in firm characteristics, as discussed above. In addition, a voluntary regime permits firms to implement corporate governance practices on their own terms, and only if such practices give rise to net benefits for the firm.

Mandatory Disclosure. The advantages of mandatory disclosure are many. Mandatory disclosure heightens compliance with the voluntary regime. As Easterbrook and Fischel state, "In a world with an anti-fraud rule but no mandatory disclosure system, firms could remain silent with impunity. If they disclosed, they could do so in any way they wished, provided they did not lie.... A mandatory disclosure system substantially limits firms' ability to remain silent." ${ }^{\text {111 }}$ In other words, mandatory disclosure embodies a recognition that the market alone is not sufficient

111 Easterbrook \& Fischel, "Mandatory Disclosure and the Protection of Investors" supra note 1 at 680. 
to encourage voluntary action. Furthermore, mandatory disclosure may actually encourage compliance: If a firm knows that the market is watching its corporate governance practices, it will have a greater incentive to comply with the voluntary guidelines that investors deem desirable.

Indeed, this prediction is borne out in recent empirical research. ${ }^{112}$ Each year, one of Canada's leading national newspapers, The Globe \& Mail, conducts a review of corporate governance practices for companies listed in the benchmark S\&P/TSX index based on a ranking that it devises in the "Board Games" series. ${ }^{113}$ The 2004 Board Games series suggests that firms' voluntary adoption of corporate governance practices came in part as a response to the previous Board Games rankings. ${ }^{114}$ However, one issue is that Board Games and other rankings prompt some "skin-deep" changes only. ${ }^{115}$ Nevertheless, the Board Games series states explicitly that many firms did make substantial changes in year three improving over years one and two of the study.

Mandatory disclosure also provides investors with a certain minimum amount of information on which to base their investment decisions. It attacks the classic problem of information asymmetry between the investor and the issuer. Investors seek to determine whether the price of the security is fair and whether the issuer is credible. ${ }^{116}$ Mandatory disclosure serves to reduce the adverse impact of information asymmetry in the capital markets. It also controls other variables, such as the time, place, and manner of the disclosure. ${ }^{117}$ In other words, it ensures that information will be conveyed to investors in a standardized manner. ${ }^{118}$

\footnotetext{
112 See Janet McFarland, “Governance Changes More Than Skin Deep” THE GLOBE \& MAIL (24 September 2003).

113 Elizabeth Church and Janet McFarland, "Board Games" THE GLOBE \& MAIL (12 - 15 October 2004).

114 Edward Greenspon, "Seeking the unvarnished truth about corporate governance" THE GLOBE \& MAIL (9 October 2004) A2.

115 See Janet McFarland, supra note 112.

116 Ronald J. Gilson \& Reinier H. Kraakman, “The Mechanisms of Market Efficiency” (1984) 70 VA. L. REV. 549 at $594-595$.

117 Easterbrook \& Fischel, "Mandatory Disclosure and the Protection of Investors" supra note 1 at 680.

118 For example, in Canada, investors can turn to the "Statement of Corporate Governance Practices" in the annual report or information circular for information concerning the number of independent directors and the composition of the various committees.
} 
Another advantage of mandatory disclosure is that it reduces the conflicting interests of directors, managers, and other agents, for example. ${ }^{119}$ For instance, management may want to control the board of directors by having more of its own members on the board than there are independent directors. Management may also want the CEO to be the chair of the board. On the other hand, board members may feel differently; they may seek to limit the perception of conflict and support the implementation of a fully independent board, with independent committees of the board and a separation between the roles of CEO and chair. Shareholders will want information pertaining to such practices and will assess the potential for the firm to suffer from conflicts of interest. This information will be relevant to the investment decision. In addition, the disclosure of such information may reduce the actual conflict between agents, since disclosure of "negative" information may hurt the company as a whole.

It is true that there are incentives for voluntary disclosure, as noted above. However, one of the drawbacks of voluntary disclosure not discussed above involves a credibility problem. ${ }^{120}$ That is, management is likely to make self-serving voluntary disclosures, revealing only information that reflects well on them. They may refrain from disclosing information relating to poor firm performance and may attempt to convince the market that adopting a particular practice is not in the company's or shareholders' best interest. Mandatory disclosure solves the credibility problem. In addition, with mandatory disclosure, the investing public will know what governance standards the firm has (and has not) adopted. Indeed, mandatory disclosure is perhaps the most important aspect of corporate governance reform because it provides transparency and thereby enables investors to make fully informed decisions. ${ }^{121}$

The argument here has been that a "partially mandatory" is optimal: firms should be able to choose which governance standards they will adopt but there should be compulsion to disclose

119 Paul G. Mahoney, "Mandatory Disclosure as a Solution to Agency Problems" (1995) 62 U. CHI. L. REV. 1047 at 1051 .

120 Healy \& Palepu, supra note 1 at 425

121 Of course, even mandatory disclosure does not necessarily yield the "full disclosure" intended in the spirit of the law. For example, the Statement of Corporate Governance Practices generates very different disclosure from different companies, much of which cannot be called "full disclosure." This is part of the reason that the OSC will be taking over the responsibility for corporate governance from the TSX. See e.g. Howlett, supra note 64, who reports that in 2001, 46\% of companies with less than $\$ 500$ million in assets failed to comment on all of the 14 TSX guidelines and $25 \%$ of companies with more than $\$ 5$ billion in assets failed to comment on all of the 14 TSX guidelines. 
choices as a matter of law. The rationale underlying this policy prescription is that market mechanisms will lead firms to choose optimal corporate governance terms and the result will be a high rate of compliance with best practices at lower aggregate costs to market participants. Yet an important question arises: if we can rely on market forces to compel issuers to follow best practice guidelines, why are we unable to rely on market forces to compel them to choose the appropriate amount of disclosure?

While there are incentives for voluntary behaviour relating to disclosure, there are powerful disincentives. In particular, issuers always have an incentive to disclose only the minimum amount of information that they are required to disclose and they will be disinclined to disclose information which may be viewed by the market as "bad news". Market pressure to disclose will be weak if an issuer's competitors choose not to disclose such information. Therefore investors may not be able to rely on voluntary behaviour with respect to this (often crucial) news.

The possibility that firms might not disclose information which the market is likely to consider "bad news" gives rise not only to the credibility problem highlighted above but also to the well-known lemon problem. Investors are unable to discern which issuers are truthful; investors therefore discount the prices that they will offer for all securities. ${ }^{122}$ High-quality issuers exit the public market, forgoing a potentially valuable investment opportunity, because they are unable to obtain a fair price for their securities. ${ }^{123}$ Low-quality issuers remain in the market and "[a]s a result, investors discount still more the prices they will pay. This in turn only drives more honest issuers away from the market and exacerbates the adverse selection problem." ${ }^{124}$ Mandatory disclosure can prevent both the credibility problem and the downward cycle that the lemon problem can pose.

Furthermore, once disclosure is required, firms will come under greater public/market scrutiny if they do not comply with existing corporate governance guidelines. They will have to provide a compelling, rational explanation for why they have not complied. Mandatory disclosure

\footnotetext{
122 George A. Akerlof, "The Market for "Lemons": Quality Uncertainty and the Market Mechanism" (1970) 84 Q.J. ECON. 488 (elucidating the adverse selection problem).

See Stewart C. Myers \& Nicholas S. Majluf, "Corporate Finance and Investment Decisions When Firms Have Information that Investors Do Not Have" (1984) 13 J.FIN. ECON. 187, 209.

$124 \quad$ Bernard S. Black, "Information Asymmetry, the Internet, and Securities Offerings" (1998) 2 J. Small \& Emerging Bus. L. 91 at 92.
} 
is more effective than voluntary disclosure here because it will ensure that all firms provide information that investors can use to make their investment decisions and also provides a baseline against which all issuers can readily be evaluated. The disclosure enables investors to react to governance choices on the basis of full information.

In addition, mandatory disclosure prevents investors from having to draw inferences about governance choices, and reasons for such choices, when firms choose to be silent. There may be a number of reasons for non-disclosure of governance choices (such as bad news and a mere desire not to be transparent about governance structures). An investor cannot simply conclude that non-disclosure is due to a problem with the governance structure or it may forgo a valuable investment opportunity. It is difficult for investors to reach informed conclusions if there is no disclosure requirement since firms may choose not to disclose information relating to governance that investors require. By contrast, if there is rule requiring explanation of the governance choices (i.e. mandatory disclosure), investors avoid having to draw conclusions from ambiguous non-disclosure. They know specifically why a firm has made the particular governance choice it has.

Admittedly, one could argue that compelling disclosure where it is not forthcoming must entail penalties and that the system is therefore mandatory. It is true that a disclosure requirement does indeed necessitate public enforcement action of some sort. However, the costs to the state (or arm's length regulator) of ensuring disclosure is adequate are surely less than the costs of monitoring whether a firm has complied with corporate governance standards across the board. The regulator still has a role in ensuring that disclosure is accurate but the costs of this process are likely less than the costs of examining firms' governance regimes as a whole. Thus the contention here is that a partially mandatory structure lessens but does not eradicate the need for monitoring and enforcement activities by regulators.

Firms may not comply with disclosure requirements. As noted in Part II, there are indeed drawbacks to the command-and-control structure, and this is one of them. To begin, the issue is one that plagues capital markets regulation generally: How does the state ensure that those who do not comply with the law are penalized for the market abuse they occasion? The problem lies 
not simply in the mandatory aspect of the disclosure feature of the governance regime but in the enforcement of securities violations generally. Further, the issue is one relating to the severity of the penalties for noncompliance. If firms are not complying because it is more cost-effective for them to absorb the penalty for noncompliance, then clearly the penalty itself is not harsh enough. In any case, as the Globe and Mail Board Games series discussed above highlights, an increasing number of firms have been complying with the obligation to disclose information relating to corporate governance practices. Thus, the threat of noncompliance with mandatory disclosure does not seem to be a major drawback to its implementation.

In sum, this argument in favour of mandatory disclosure stems from a belief that the market mechanism is not in and of itself sufficient to encourage compliance with a voluntary code of corporate governance practices. Firms will likely disclose only positive information if disclosure is not mandatory (the credibility problem). In addition, mandatory disclosure provides transparency creating a level playing field among investors in terms of the information that they have about the firm's governance practices. Thus, low compliance combined with the credibility problem constitutes a major drawback of a voluntary system, while cost is a significant disadvantage of a mandatory regime. An optimal regime would be one that recognizes investors' need for protection, on the one hand, and issuers' need for flexibility, on the other. The partially mandatory structure meets both of these concerns. It lessens the need for penalties for noncompliance (a main feature of the mandatory system) because the disclosure itself is mandatory, compelling firms to comply with the voluntary guidelines or suffer investor repulsion.

Empirical Questions. One of the weaknesses of an argument such as this is the lack of empirical evidence for the assumptions on which it is based. In particular, this argument for a partially mandatory regime is predicated on the assumption that compliance rates under that regime will be comparable to such rates under a fully mandatory regime. While evidence in the corporate governance sphere relating to these questions is lacking, empirical evidence from other disciplines is informative. For example, Khanna and Damon examine the effect of the "33/50" programme, a voluntary environmental regulatory initiative designed to curb toxic releases. They find that participation in the programme led to a statistically significant decline in toxic releases 
over the period 1991-1993. ${ }^{125}$ This leads the authors to conclude that there are strong incentives for participation in the programme, including the benefits due to public recognition and the potentially avoided costs of liabilities. However, Khanna and Damon also conclude that participation in voluntary initiatives depend a considerable extent on the existence of a regulatory framework that would impose penalties on firms that do not undertake proactive measures for self-regulation. They argue that mandatory regulation provides a "backstop" for voluntary programmes. ${ }^{126}$ The evidence and conclusions from the Khanna and Damon study are instructive in this instance. The study indicates the importance of mandatory regulation as one factor in a regime that has a voluntary component. Thus, one can expect that a partially mandatory regime, such as the one proposed here, will have high compliance rates because of the mandatory disclosure element. Of course, compliance is not the only regulatory concern; the optimality analysis will extend beyond theconsideration of compliance to that of flexibility. It is to this issue that we now turn.

\section{(c) Flexibility in Governance Structures}

Part II of this article isolated a number of costs present in mandatory regimes and compared these to costs inherent in the voluntary structure. In the mandatory structure, the state bears design, implementation, and enforcement costs, while issuers bear compliance costs (which can be direct or indirect). In a voluntary regime where the state has established a code of suggested best practices, the state continues to bear policy design and implementation costs. However, it does not incur surveillance and enforcement costs to the same extent. Under the voluntary regime, firms need not incur compliance costs, but they will incur costs to institute standards (e.g., internal management time) and disclosure costs. In choosing whether or not to comply with the voluntary regime, firms assess the costs and benefits of their compliance and undertake action that results in the greatest net benefit to the firm.

125 Khanna and Damon, supra note 2. The 33/50 programme was implemented by the Environmental Protection Agency in 1991 as a means to encourage firms to voluntarily reduce their toxic emissions. Firms had flexibility in the amount of reductions undertaken and the means to achieve them.

$126 \quad$ Ibid. at 23. 
How do these costs and benefits break down in a partially mandatory regime? At the outset, it appears that there is no cost saving at all, since the hybrid structure gives rise to costs that exist in the mandatory regime. Specifically, the state bears the costs of designing and implementing the voluntary code, as well as certain enforcement costs, since disclosure under the system is mandatory. Compliance costs for issuers also arise because of the disclosure requirement (though some regimes create less onerous requirements for smaller issuers in terms of the disclosure requirement).

The compliance costs in a partially mandatory regime are likely less, since there are fewer legal requirements with which the issuer must comply. However, this advantage should be framed in terms of the flexibility that is afforded to issuers in determining the extent to which they adhere to the best practices. Firms are able to continue to assess the costs and benefits of suggested governance practices and implement those that would result in the highest net benefit to each. The partially mandatory regime is thus more responsive to firm interests than a wholly mandatory structure, while not ignoring investors' need for information relating to firms' corporate governance practices.

The fact that partially mandatory regimes respond to both issuer and investor concerns in a cost-effective manner undermines the usual justification for mandatory corporate governance legislation. As noted above, an optimal governance regime is one that takes into account the benefits and costs to all stakeholders; a mandatory regime does not adequately respond to issuers' concerns relating to both cost and flexibility. Some regulators might respond that the mandate of the regulator is not to appease various capital markets stakeholders but to ensure that "integrity" and "confidence" typify the capital markets. ${ }^{127}$ The mandate is a balancing act, no doubt, but the decrease in integrity and confidence under a partially rather than wholly mandatory regime arguably is negligible though this point needs to be pursued in further research as discussed below. In practical terms, this conclusion suggests that Canadian, U.K., and Australian capital markets do not have less "integrity" than the U.S. market. Partially mandatory structures can achieve the law's objectives at less cost. 
It may be argued that the only reason that some jurisdictions, such as those discussed above, can have a partially mandatory regime is that there is one regime that has adopted a wholly mandatory approach (i.e., the United States with SOX). Issuers will be compliant under a partially mandatory (or voluntary?) regime because they seek to remain competitive with their peers in other jurisdictions. They are also aware of the heightened costs that could come with a mandatory - and potentially more costly and less flexible - regime.

On the one hand, it is not clear whether an entire mandatory regime needs to be established in order for issuers to understand that their current governance regime could become more strict. The Canadian and U.K. partially mandatory governance regimes were in place long before Sarbanes-Oxley. ${ }^{128}$ On the other hand, onerous legislation in another jurisdiction no doubt influences the behavior of firms outside the jurisdiction, for reasons relating to competition. ${ }^{129}$ Much depends on the size of the market in which the mandatory legislation is implemented. Firms cross-listed in the jurisdiction with the mandatory regime may be obliged to comply with the mandatory legislation, as was the case with Sarbanes-Oxley. ${ }^{130}$

These questions, and the present theoretical argument in favor of voluntary governance regimes, establish the groundwork for future empirical research. The research should examine the success of voluntary and partially voluntary regimes, and, in particular, the propensity of firms to adopt governance practices voluntarily. For example, it is possible that firms not subject to the Sarbanes-Oxley Act may voluntarily comply with this legislation in order to remain competitive. From a policy perspective, the upshot of this argument is that mandatory regulation is a de facto

128 The TSX regime has been in place since the 1995 adoption of the Dey Report. See TSX COMPANY MANUAL, $\S 472$. As for the U.K. regime, the 1998 Combined Code created by the Hampel Committee was actually an update of the CODE OF BEST PRACTICE drafted by the Cadbury Committee in 1992. See Report of the Committee on the Financial Aspects of Corporate Governance: The Code of Best Practice (Cadbury Code), Dec. 1, 1992. Although the NYSE did have some corporate governance listing requirements prior to the enactment of SOX, those requirements were relatively minor, relating primarily to audit committees. See NYSE Rules, $\S 303$.

129 For example, in research relating to the Anand, Milne \& Purda project, supra note 34, the author has found that Canadian companies routinely express their awareness of SOX in annual disclosure documents and that they state their objective to comply with SOX in the absence of a legal requirement to do so.

130 Of course, this is not necessarily the case. For example, Canadian companies cross-listed in the United States are allowed to use their AIF to comply with some U.S. requirements; similarly, some Canadian cross-border issuers are permitted to use SEC Forms to meet certain Canadian disclosure requirements. 
requirement for firms outside the jurisdiction, even those that are not cross-listed. Those firms not bound to comply may feel significant pressure to do so voluntarily. ${ }^{131}$

\section{Conclusion}

This article encourages market participants, including regulators, to acknowledge that firms have incentives to adopt enhanced governance practices voluntarily and to make disclosure about same. It also recognizes certain advantages in having a mandatory disclosure regime. The article argues that an optimal governance regime is one that takes into account the benefits and costs to all stakeholders, particularly issuers and investors. The benefits of a corporate governance regime are straightforward and relate mainly to enhanced accountability. The cost analysis should be completed by weighing the level of expected compliance against the total costs of the regime adopted by regulators. A partially mandatory structure yields a high level of compliance at lower cost than a wholly mandatory regime. While a wholly mandatory structure may yield slightly better compliance, its costs are likely to be much higher. Thus, a partially mandatory structure that minimizes costs but encourages compliance is optimal.

131 Anand, Milne \& Purda, supra note 34. 


\section{APPENDIX 1}

The following countries allow firms to comply with governance guidelines voluntarily. Firms are not required to disclose the extent of their compliance.
1. Belgium
2. Brazil
3. Denmark
4. France
5. Iceland
6. Lithuania
7. Macedonia
8. Peru
9. Poland
10. Russia
11. South Africa
12. Switzerland

The following countries allow firms to comply with governance guidelines on a voluntary basis. Disclosure of governance practices is required, however.

1. Australia

2. Austria

3. Canada

4. Finalnd

5. Germany

6. Italy

7. Nertherlands

8. Singapore

9. Slovakia

10. Slovenia

11. Spain

12. Sweden

13. Turkey

14. United Kingdom

The following countries have mandatory governance standards which include mandatory disclosure of governance practices.

1. Pakistan

2. United States 


\section{Summary:}

\begin{tabular}{|c|c|}
\hline Corporate Governance Regime Type & Number of Countries \\
\hline Fully Voluntary & 12 \\
\hline Partially Mandatory & 14 \\
\hline Fully Mandatory & 2 \\
\hline Total Countries Examined & 28 \\
\hline
\end{tabular}

